\title{
Seasonal and interannual variations of community metabolism rates of a Posidonia oceanica seagrass meadow
}

\author{
W. Champenois and A. V. Borges* \\ Chemical Oceanography Unit, Université de Liège, Liège, Belgium
}

\begin{abstract}
We report gross primary production (GPP), community respiration (CR), and net community production (NCP) over a Posidonia oceanica meadow at $10 \mathrm{~m}$ in Corsica (Bay of Revellata) based on the open water $\mathrm{O}_{2}$ mass balance from a data set of hourly measurements with an array of three $\mathrm{O}_{2}$ optodes deployed from August 2006 to October 2009. The method was checked by comparison with discrete measurements of metabolic rates derived from benthic chamber incubations also based on the diel change of $\mathrm{O}_{2}$. This comparison was satisfactory and actually highlights the potential caveats of benthic incubation measurements related to $\mathrm{O}_{2}$ accumulation in small chambers leading to photorespiration and an underestimation of GPP. Our data confirmed previous $P$. oceanica meadows GPP and CR values, strong seasonal variations, and net autotrophy. High-resolution data revealed strong interannual variability, with a decrease of GPP by $35 \%$ and NCP by $87 \%$ during 2006-2007 characterized by a mild and less stormy winter compared with 2007-2008 and 2008-2009. P. oceanica meadows are then expected to decrease export of organic carbon to adjacent communities (decrease of NCP), since a decrease in frequency and intensity of marine storms is expected in the future in the Mediterranean Sea as a result of a northward shift of the Atlantic storm track.
\end{abstract}

The production, degradation, export, and burial of organic matter in coastal environments are higher than in the open ocean (Wollast 1998), and the coastal ocean represents one of the most biogeochemical active areas of the biosphere. Macrophyte ecosystems constitute an important component of the coastal ocean, despite a modest surface area $(<2 \%$ of the world ocean). Macrophyte ecosystems host high biodiversity and stabilize shorelines, providing valued ecosystem goods and services (Costanza et al. 1997). Macrophyte ecosystems are also characterized by intense carbon flows (Duarte et al. 2010). Among macrophyte ecosystems, seagrass meadows are characterized by a gross primary production (GPP) at a global scale ranging between 296 and $591 \mathrm{Tg} \mathrm{C} \mathrm{yr}^{-1}$ and a net organic carbon burial ranging between 25 and $50 \mathrm{Tg} \mathrm{C} \mathrm{yr}^{-1}$ (Duarte et al. 2010). This imbalance of GPP and net organic carbon burial implies that a large fraction of organic carbon produced in seagrass meadows is either exported to adjacent communities or degraded within the community (Heck et al. 2008). The different fates of autochthonous organic carbon from seagrass meadows ecosystems will depend on the community metabolic status.

The community metabolic status is quantified by the net community production (NCP), which corresponds to the difference between GPP and community respiration (CR, sum of autotrophic and heterotrophic respiration) in both the pelagic and benthic compartments (Odum 1956). The community metabolic status will determine whether a community exports organic carbon to adjacent systems (net autotrophic; NCP $>0$ ) or whether a community requires external organic carbon inputs to sustain its own metabolism (net heterotrophic; NCP $<0$ ). However, the community metabolic status of coastal environments as net

\footnotetext{
*Corresponding author: alberto.borges@ulg.ac.be
}

autotrophic or net heterotrophic has been the subject of a long lasting debate (Smith and Hollibaugh 1993; Wollast 1998). One of the reasons for this debate is the lack of data for resolving the temporal variability of carbon cycling in highly dynamic coastal ecosystems and for adequately describing the diversity and spatial heterogeneity of these ecosystems. Further, little information is available on interannual variability of carbon cycling in coastal environments that can be driven by climatic forcing or on longterm trends due to anthropogenic pressures (Gypens et al. 2009).

Reliable estimates of the community metabolic status are hampered by the conceptual problems associated with ${ }^{14} \mathrm{C}$ estimation of primary production (Peterson 1980), the strong spatial heterogeneity within an ecosystem (Gazeau et al. 2005a,b), and the high temporal variability that cannot be easily captured with classical incubation based approaches (Karl et al. 2003). Gazeau et al. (2005a) reviewed the advantages and caveats of several methods to estimate NCP and recommended the use of integrative mass balance approaches of relevant variables such as $\mathrm{O}_{2}$ (Odum 1956; Caffrey 2004).

Posidonia oceanica is an endemic seagrass of the Mediterranean Sea, with meadows that cover $1 \%$ to $2 \%$ of the total surface (Pasqualini et al. 1998) and host between $\sim 20 \%$ and $\sim 25 \%$ of the biodiversity of the Mediterranean Sea (Boudouresque 2004). Community metabolism rate measurements of $P$. oceanica have been exclusively derived from the change of $\mathrm{O}_{2}$ in benthic chambers and have been reported in a restricted number of meadows in Corsica (Frankignoulle and Bouquegneau 1987), Mallorca (Holmer et al. 2004; Gazeau et al. 2005b; Barrón et al. 2006), and Greece (Apostolaki et al. 2010a). Full seasonality (at best with a monthly resolution) has only been described for GPP, CR, and NCP in Magalluf Bay (Barrón et al. 2006) and Sounion (Apostolaki et al. 


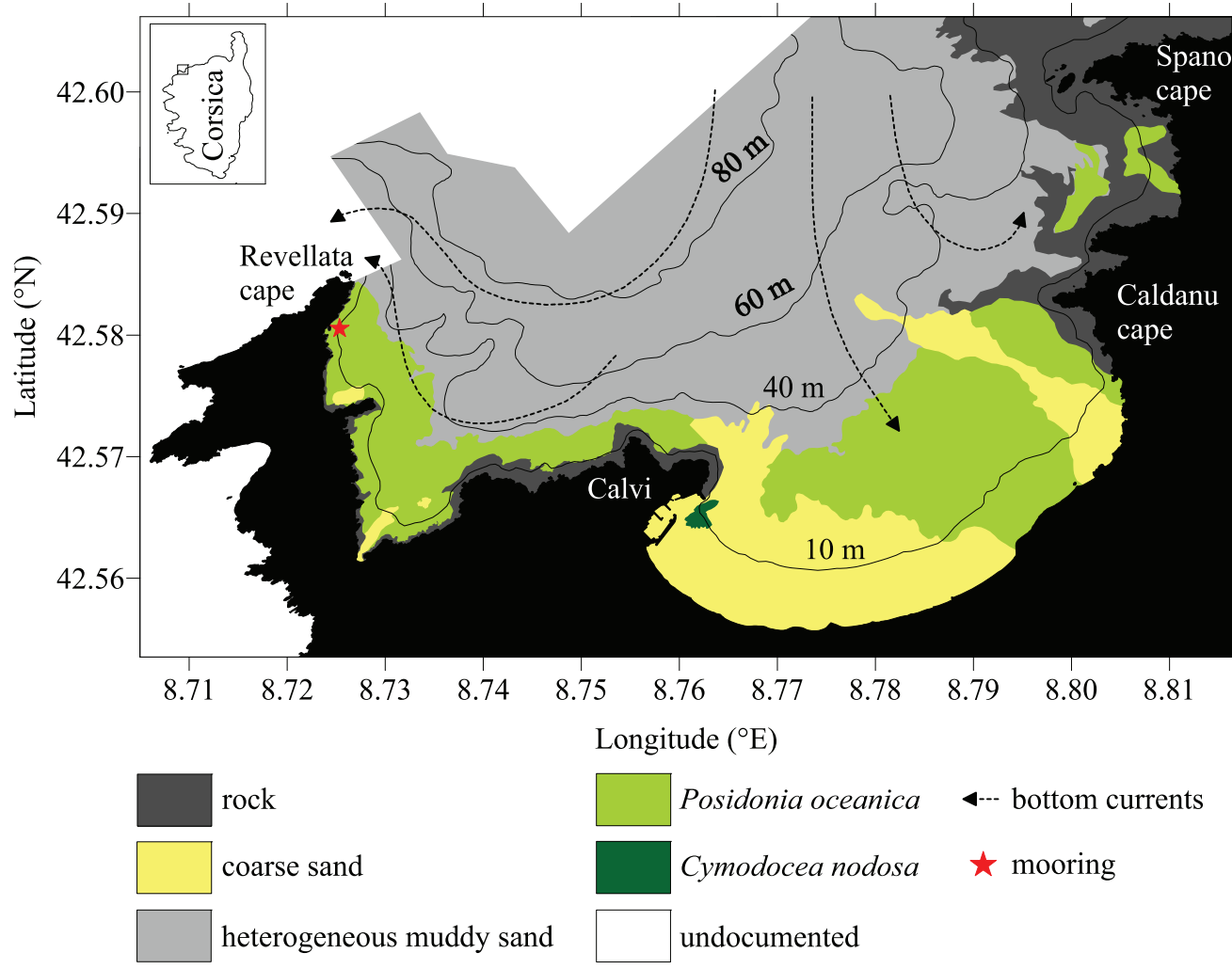

Fig. 1. Map of study site showing the main benthic communities, bathymetry, pattern of climatological bottom water residual currents, and location of the mooring. The Bay of Revellata extends from Revellata cape to the city of Calvi, the Bay of Calvi extends from the city of Calvi to Spano cape.

2010a) and for NCP in the Bay of Revellata (Frankignoulle and Bouquegneau 1987). A fair amount of data on leaf growth based on marking approaches have been gathered in several P. oceanica meadows (Bay 1984; Pergent-Martini et al. 1994), although these estimates are not directly comparable with community metabolic rates (GPP, NCP). Little if anything is known on short-term variability (submonthly scale) and interannual variability of community metabolism in seagrass meadows in general and in $P$. oceanica meadows in particular. Some data sets of community metabolism in seagrass meadows span several years, 4 yr in Baffin Bay (Odum and Wilson 1962) or 2 yr in Laguna Madre (Reyes and Merino 1991); however, the temporal resolution of data was not sufficient to resolved interannual variations.

Here, we report a data set of $\mathrm{O}_{2}$ measurements at hourly intervals obtained quasicontinuously from August 2006 to October 2009 on a shallow mooring (10-m depth) with an array of three $\mathrm{O}_{2}$ optodes covering the whole water column from surface to bottom over a $P$. oceanica meadow in the Bay of Revellata (Corsica; Fig. 1). Community metabolic rates (GPP, CR, and NCP) were calculated on a daily basis from this data set by the open water mass balance of $\mathrm{O}_{2}$ approach (Odum 1956) and compared with discrete estimates calculated from $\mathrm{O}_{2}$ changes in benthic chambers (with a 2- to 3-month resolution). Seasonality of community metabolic rates is described in conjunction with meadow biomass data, while interannual variability of community metabolic rates is discussed in light of environmental variables (water temperature and wind speed).

\section{Methods}

Description of the study area-The Bay of Revellata and the Bay of Calvi (total surface $\sim 22 \mathrm{~km}^{2}$ ) open to the Ligurian Sea on the northeast with a border of $\sim 6 \mathrm{~km}$ (Fig. 1). The area is submitted to northeast winds during winter and the rest of the year to Libeccio blowing from the southwest. Owing to the geographic orientation, the Bay of Revellata and the Bay of Calvi are relatively well protected from southwest winds. The seawater temperature ranges annually from $\sim 13^{\circ} \mathrm{C}$ in late winter to $\sim 26^{\circ} \mathrm{C}$ in late summer. From May to September, there is a well-marked thermocline at $\sim 25 \mathrm{~m}$, while in winter the mixed layer depth exceeds $100 \mathrm{~m}$. The only fresh water inputs are from surface runoff during storm events, and salinity is seasonally virtually constant at $\sim 38$.

There are five main benthic communities in the Bay of Revellata and the Bay of Calvi (Fig. 1): shallow rocky substrates covered by photophilic macroalgae (Halopteris scoparia, Dictyota dichotoma, Padina pavonica, Cystoseira balearica); bare coarse sand; Cymodocea nodosa meadows; $P$. oceanica meadows extending from $\sim 5 \mathrm{~m}$ to $<40 \mathrm{~m}$; heterogeneous muddy sand (below $40 \mathrm{~m}$ ) rich in debris of $P$. oceanica leaves, with sciaphilic macroalgae down to $100 \mathrm{~m}$.

Mooring and anemometer-The mooring was deployed by self-contained underwater breathing apparatus (scuba) 
dive over the $P$. oceanica meadow at $10-\mathrm{m}$ depth in the northern part of the Bay of Revellata $\left(8.733^{\circ} \mathrm{E}, 42.567^{\circ} \mathrm{N}\right)$ close to the Stareso research station. Aanderaa $\mathrm{O}_{2}$ optodes (3835) mounted on Alec Instruments loggers were deployed at 4.5-, 7.0-, and 9.5-m depth, in addition to a Wetlabs fluorometer $(4.5 \mathrm{~m})$. Oxygen saturation level and temperature were measured and logged at hourly intervals to accommodate the typical duration of deployments ( $\sim 3$ months) and lithium battery life at that sampling rate ( $\sim 5$ months). Oxygen concentrations were computed from $\mathrm{O}_{2}$ saturation level, seawater temperature, and a salinity of 38, using the algorithm given by Benson and Krause (1984). During the field cruises, the $\mathrm{O}_{2}$ optodes were retrieved from the mooring by scuba dive on 16 occasions for servicing, data download, and stability check (04 August 2006, 01 October 2006, 05 December 2006, 21 February 2007, 05 April 2007, 22 May 2007, 19 August 2007, 31 October 2007, 07 February 2008, 30 April 2008, 22 August 2008, 02 December 2008, 01 March 2009, 09 June 2009, 13 August 2009, and 03 November 2009). To check stability of the sensors, the three $\mathrm{O}_{2}$ optodes were placed in a container with 100 liters of seawater at in situ temperature that was saturated in $\mathrm{O}_{2}$ by bubbling ambient air for $2 \mathrm{~h}$. Bubbling was then stopped, and during a period of $\sim 12 \mathrm{~h}, 7$ to 10 water samples were collected regularly with Tygon tubing, transferred to $300-\mathrm{mL}$ biological oxygen demand (BOD) bottles, and fixed with Winkler reagents. Oxygen was measured by Winkler titration with a potentiometric endpoint determination using the protocol, reagents, and calibrations given by Knap et al. (1996). The comparison of $\mathrm{O}_{2}$ measured by optodes and by Winkler titration allowed us to determine the accuracy of $\mathrm{O}_{2}$ measurements by optodes, which was better than $\pm 2.0 \mu \mathrm{mol} \mathrm{kg}^{-1}$. The accuracy was not significantly different among the three $\mathrm{O}_{2}$ optodes and remained stable during the study period. The precision of $\mathrm{O}_{2}$ measurements by the $\mathrm{O}_{2}$ optodes was better than $\pm 0.1 \mu \mathrm{mol} \mathrm{kg}-1$, based upon the standard deviation on the mean of 30 measurements during $30 \mathrm{~s}$, which is the standard configuration of measurements used. The precision was not significantly different among the three $\mathrm{O}_{2}$ optodes and remained stable during the study period. The reported precision and accuracy are similar to those determined for Aanderaa optodes by Tengberg et al. (2006). During the study period, the only malfunction of the $\mathrm{O}_{2}$ optodes was due to a defective lithium battery leading to the loss of $\mathrm{O}_{2}$ and temperature data at $7.0-\mathrm{m}$ depth during $17 \mathrm{~d}$ (15 May 2007 to 01 June 2007). For this time period, $\mathrm{O}_{2}$ and temperature data at $7.0 \mathrm{~m}$ were filled by using the average values from 9.5 and $4.5 \mathrm{~m}$.

Sea water (1 liter) was sampled near the fluorometer by scuba dive, filtered on glass fiber filters $(47 \mathrm{~mm}, \mathrm{GF} / \mathrm{F}$ Whatman), and stored frozen $\left(-20^{\circ} \mathrm{C}\right)$ until chlorophyll $a$ (Chl a) determination by fluorometry, after overnight extraction in $90 \%$ acetone at $4^{\circ} \mathrm{C}$ according to Lorenzen and Jeffrey (1978). Comparison of Chl $a$ measured by the fluorometer on the mooring and measured discretely (see Results section) showed that the factory calibration of the fluorometer gave satisfactory values, and no further calibration was applied. The fluorometer was damaged, and data were not acquired from 01 June 2007 to 07 April 2008.
An anemometer (Thies Clima) was deployed on top of one of the buildings of the Stareso station (at 11.8-m height) at a distance of about $100 \mathrm{~m}$ from the mooring. Wind speed data were referenced at $10.0-\mathrm{m}$ height $\left(\mathrm{u}_{10}\right)$ using the algorithm given by Johnson (1999). For undetermined reasons, wind speed data were not logged from 28 August 2007 to 03 November 2007. For this time period, $\mathrm{u}_{10}$ data were filled by average values for the same period acquired in 2006, 2008, and 2009.

Computation of GPP, CR, and NCP by open water mass balance of $\mathrm{O}_{2}$-The computation of metabolic rates (GPP, $\mathrm{CR}, \mathrm{NCP}$ ) by open water mass balance of $\mathrm{O}_{2}$ is based on the Odum (1956) method: the hourly change of $\mathrm{O}_{2}$ in the mixed layer corrected for the exchange of $\mathrm{O}_{2}$ with the atmosphere during nighttime corresponds to hourly rate of $\mathrm{CR}$; the hourly change of $\mathrm{O}_{2}$ in the mixed layer corrected for the exchange of $\mathrm{O}_{2}$ with the atmosphere during daytime corresponds to hourly rate of NCP; assuming that the hourly rate of $\mathrm{CR}$ is constant through the daily cycle, hourly rate of GPP is computed as NCP - CR (where CR is a negative flux). GPP is integrated at a daily scale by multiplying the hourly rate by the photoperiod $\left(\mathrm{H}_{\mathrm{d}}\right)$. CR is integrated at a daily scale by multiplying the hourly rate by 24. Daily integrated NCP is computed as the sum of daily integrated GPP and daily integrated CR.

Since the study area was always vertically isothermal (water column mixed from surface to seafloor, see Results section), computations were made using the integrated $\mathrm{O}_{2}$ content in the whole water column $(10 \mathrm{~m})$ based on the measurements at the three depths $(4.5,7.0$, and $9.5 \mathrm{~m})$. We considered five layers: (1) 10.0 to $9.0 \mathrm{~m}$; (2) 9.0 to $7.5 \mathrm{~m}$; (3) 7.5 to $6.5 \mathrm{~m}$; (4) 6.5 to $5.0 \mathrm{~m}$; (5) $5.0 \mathrm{~m}$ to the surface. The $\mathrm{O}_{2}$ concentrations in layers 1,3 , and 5 correspond to those measured by the $\mathrm{O}_{2}$ optodes at $9.5,7.0$, and $4.5 \mathrm{~m}$, respectively, while in layers 2 and 4 they are given by the average of the two nearest $\mathrm{O}_{2}$ optodes. The data are integrated to provide the vertical integrated content of $\mathrm{O}_{2}$ $\left(\mathrm{Q}_{\mathrm{O}_{2}}\right.$ in $\left.\mathrm{mmol} \mathrm{m}^{-2}\right)$ on an hourly basis. Computations were made by considering a $24-\mathrm{h}$ cycle starting at sunrise of a given day. Daily integrated $\mathrm{CR}\left(\mathrm{mmol} \mathrm{O} \mathrm{O}^{-2} \mathrm{~d}^{-1}\right)$ is computed according to

$\mathrm{CR}=\left(\sum\left(\left(\mathrm{Q}_{\mathrm{O}_{2} \mathrm{n}}\right)_{t+1}-\left(\mathrm{Q}_{\mathrm{O}_{2} \mathrm{n}}\right)_{t}\right)+\sum \mathrm{F}_{\mathrm{O}_{2} \mathrm{n}}\right) / \mathrm{H}_{\mathrm{n}} \times 24$ (1)

where $\left(\mathrm{Q}_{\mathrm{O}_{2} \mathrm{n}}\right)_{t+1}-\left(\mathrm{Q}_{\mathrm{O}_{2} \mathrm{n}}\right)_{t}$ is the change in $\mathrm{Q}_{\mathrm{O}_{2}}$ during nighttime $\left(\mathrm{Q}_{\mathrm{O}_{2} \mathrm{n}}\right)$ between two hourly intervals $(t), \mathrm{F}_{\mathrm{O}_{2} \mathrm{n}}$ is the air-sea $\mathrm{O}_{2}$ exchange at each $t$ during nighttime computed using the Ho et al. (2006) gas transfer parameterization as a function of wind speed and measured $\mathrm{u}_{10}$ (where the efflux of $\mathrm{O}_{2}$ from water to atmosphere corresponds to positive $\mathrm{F}_{\mathrm{O}_{2} \mathrm{n}}$ ), and $\mathrm{H}_{\mathrm{n}}$ is the nighttime duration given by

$$
\mathrm{H}_{\mathrm{n}}=24-\mathrm{H}_{\mathrm{d}}
$$

where $\mathrm{H}_{\mathrm{d}}$ is computed from an astronomical model (http:// www.usno.navy.mil/USNO/astronomical-applications).

Daily integrated GPP $\left(\mathrm{mmol} \mathrm{O}_{2} \mathrm{~m}^{-2} \mathrm{~d}^{-1}\right)$ is computed according to 


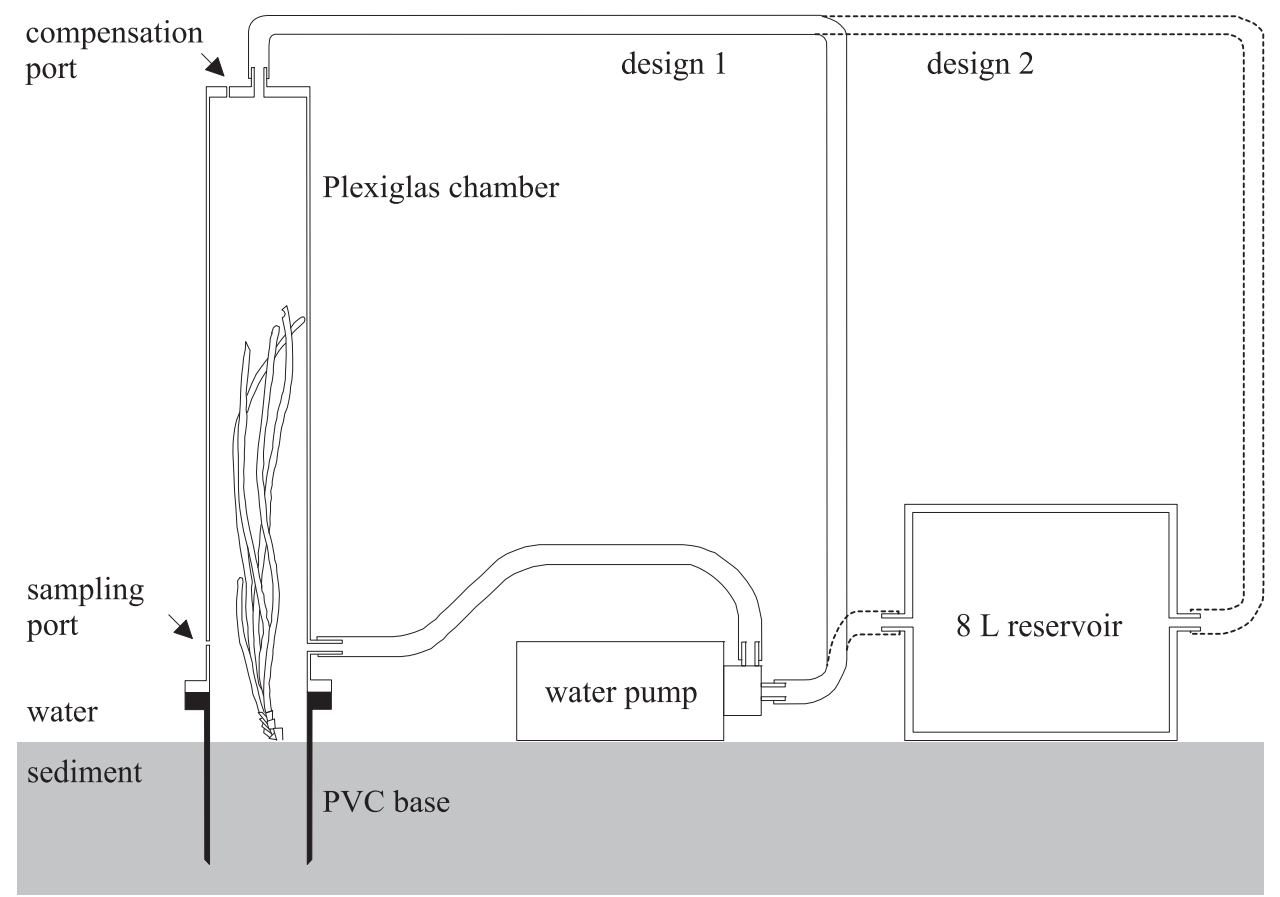

Fig. 2. Benthic chamber used for 24-h incubations over a $P$. oceanica meadow. For design 1, the water pump was used a few minutes prior to sampling to homogenize the incubated volume. For design 2, a volume of 8 liters was added to the circuit and the water pump run throughout the incubation cycle.

$$
\mathrm{GPP}=\sum\left(\left(\mathrm{Q}_{\mathrm{O}_{2} \mathrm{~d}}\right)_{t+1}-\left(\mathrm{Q}_{\mathrm{O}_{2} \mathrm{~d}}\right)_{t}\right)+\sum \mathrm{F}_{\mathrm{O}_{2} \mathrm{~d}}-\mathrm{CR}
$$

where $\left(\mathrm{Q}_{\mathrm{O}_{2} \mathrm{~d}}\right)_{t+1}-\left(\mathrm{Q}_{\mathrm{O}_{2} \mathrm{~d}}\right)_{t}$ is the change in $\mathrm{Q}_{\mathrm{O}_{2}}$ during daytime $\left(\mathrm{Q}_{\mathrm{O}_{2} \mathrm{~d}}\right)$ between two $t, \mathrm{~F}_{\mathrm{O}_{2} \mathrm{~d}}$ is the air-sea $\mathrm{O}_{2}$ exchange at each $t$ during daytime.

On some occasions rapid changes of water temperature in conjunction with high wind speed events indicated a drastic change of water mass (see Results section), and metabolic data for these periods were discarded.

Computation of GPP, CR, and NCP by mass balance of $\mathrm{O}_{2}$ in benthic chambers-Benthic chamber incubations for the determination of GPP, CR, and NCP were carried out on 16 occasions during the study period (06 August 2006, 02 October 2006, 05 December 2006, 20 February 2007, 04 April 2007, 28 May 2007, 24 August 2007, 29 October 2007, 05 February 2008, 28 April 2008, 15 August 2008, 03 December 2008, 24 February 2009, 08 June 2009, and 12 August 2009). The benthic chamber (Fig. 2) consisted of a polyvinyl chloride $(\mathrm{PVC})$ cylindrical base $(9 \mathrm{~cm}$ internal diameter, $25 \mathrm{~cm}$ internal length) and a Plexiglas cylinder ( $9 \mathrm{~cm}$ internal diameter, $61 \mathrm{~cm}$ internal length) that were used under two configurations corresponding to two different designs (Fig. 2). For design 1, a water pump plugged to the chamber was used to homogenize the water within the chamber prior to sampling during $7 \min (\sim 3$ cycles of homogenization based on total volume and pump flow) and remained stopped until the next sampling (but left plugged to the chamber). For design 2, an additional volume of 8 liters was added to the circuit, and the water pump was left plugged and running throughout the incubation (only stopped during sampling). The use of rigid benthic chambers has the advantage of avoiding artificial pumping of pore waters into the chamber that can occur as a result of the movement of flexible chambers due to wave action. The disadvantage of rigid benthic chambers is that the concentration of solutes in the chamber has to be corrected for the volume and chemical content of external water that replaces the volume of sampled water, requiring additional chemical determinations for the external water. The volume of external water introduced into the chamber during sampling was 0.5 liters for a total incubated volume of 5.5 liters and 13.5 liters for designs 1 and 2, respectively. The water was sampled at the bottom of the Plexiglas cylinder, and external water passively entered the Plexiglas cylinder from the top to avoid direct contamination of sampled water.

Three PVC bases were inserted $\sim 15 \mathrm{~cm}$ into the sediment to surround $P$. oceanica shoots at three locations randomly chosen in a $\sim 20-\mathrm{m}$ radius of the mooring $24 \mathrm{~h}$ before the start of the incubation. During the study period, the PVC bases enclosed on average $\sim 6$ shoots, ranging between 3 and 12 shoots. The incubations started at sunrise $\left(\mathrm{T}_{0}\right)$ when the Plexiglas cylinders were placed on the PVC bases, and the first sampling was carried out with $60-\mathrm{mL}$ plastic syringes, eight from each chamber and eight for outside water. Sampling was carried out in a similar fashion at sunset of the same day $\left(\mathrm{T}_{1}\right)$ and at sunrise of the next day $\left(\mathrm{T}_{2}\right)$. At the end of each scuba dive, the water was 
transferred from syringes to $60 \mathrm{~mL}$ BOD bottles and fixed with Winkler reagents. The analysis of $\mathrm{O}_{2}$ was carried by Winkler titration as described above. Computations of community metabolic rates for the benthic chamber incubations are also based on the principle of the Odum (1956) approach.

The net change of $\mathrm{O}_{2}$ due to $\mathrm{CR}\left(\Delta_{\mathrm{O}_{2} \mathrm{CR}}, \mathrm{mmol} \mathrm{O}_{2} \mathrm{~d}^{-1}\right)$ is given by

$$
\Delta_{\mathrm{O}_{2} \mathrm{CR}}=\left(\mathrm{Q}_{\mathrm{O}_{2} \mathrm{C}\left(\mathrm{T}_{2}\right)}-\mathrm{Q}_{\mathrm{O}_{2} \mathrm{C}\left(\mathrm{T}_{1}\right)}\right) / \mathrm{H}_{\mathrm{n}} \times 24
$$

where $\mathrm{Q}_{\mathrm{O}_{2} \mathrm{C}\left(\mathrm{T}_{1}\right)}$ and $\mathrm{Q}_{\mathrm{O}_{2} \mathrm{C}\left(\mathrm{T}_{2}\right)}$ are the content of $\mathrm{O}_{2}(\mathrm{mmol}$ $\mathrm{O}_{2}$ ) in the incubated volume (based on $\mathrm{O}_{2}$ concentration and total incubated volume) at $\mathrm{T}_{1}$ and $\mathrm{T}_{2}$, respectively.

The net change of $\mathrm{O}_{2}$ due to GPP $\left(\Delta_{\mathrm{O}_{2} \mathrm{GPP}}, \mathrm{mmol} \mathrm{O}_{2} \mathrm{~d}^{-1}\right)$ is given by

$$
\begin{aligned}
\Delta_{\mathrm{O}_{2} \mathrm{GPP}}= & \left(\left(\mathrm{Q}_{\mathrm{O}_{2} \mathrm{C}\left(\mathrm{T}_{1}\right)}-\mathrm{Q}_{\mathrm{O}_{2} \mathrm{C}\left(\mathrm{T}_{0}\right)}\right) / \mathrm{H}_{\mathrm{d}}-\right. \\
& \left.\left(\mathrm{Q}_{\mathrm{O}_{2} \mathrm{C}\left(\mathrm{T}_{2}\right)}-\mathrm{Q}_{\mathrm{O}_{2} \mathrm{C}\left(\mathrm{T}_{1}\right)}\right) / \mathrm{H}_{\mathrm{n}}\right) \times \mathrm{H}_{\mathrm{d}}
\end{aligned}
$$

where $\mathrm{Q}_{\mathrm{O}_{2} \mathrm{C}\left(\mathrm{T}_{0}\right)}$ is the content of $\mathrm{O}_{2}\left(\mathrm{mmol} \mathrm{O}_{2}\right)$ in the incubated volume at $\mathrm{T}_{0}$.

GPP and CR for each individual benthic chamber were computed from $\Delta_{\mathrm{O}_{2} \mathrm{GPP}}$ and $\Delta_{\mathrm{O}_{2} \mathrm{CR}}$, respectively, by integrating by surface area with the number of shoots of $P$. oceanica within each chamber ( $\mathrm{SN}_{c}$, numbers of shoots) and average shoot density of the meadow around the mooring $\left(\mathrm{SD}_{M}\right.$, shoots $\left.\mathrm{m}^{-2}\right)$, according to

$$
\begin{gathered}
\mathrm{GPP}=\Delta_{\mathrm{O}_{2} \mathrm{GPP}} / \mathrm{SN}_{c} \times \mathrm{SD}_{M} \\
\mathrm{CR}=\Delta_{\mathrm{O}_{2} \mathrm{CR}} / \mathrm{SN}_{c} \times \mathrm{SD}_{M}
\end{gathered}
$$

Integration of GPP and CR from $\Delta_{\mathrm{O}_{2} \mathrm{GPP}}$ and $\Delta_{\mathrm{O}_{2} \mathrm{CR}}$ based on other biometric variables such as leaf area index (LAI) or aboveground biomass provided very similar results to those from the integration based on $\mathrm{SN}_{c}$ and $\mathrm{SD}_{M}$, and this approach was preferred for simplicity.

Biometry $-\mathrm{SN}_{c}$ is the sum of $P$. oceanica shoots enclosed in the PVC base. $\mathrm{SD}_{M}$ was computed from the count of $P$. oceanica shoots within a frame $(25 \mathrm{~cm} \times 40 \mathrm{~cm}$, Gobert et al. 2003), which was thrown randomly between 10 and 15 times within a $\sim 20$-m radius of the mooring. Shoots of $P$. oceanica within each benthic chamber were collected for the determination of leaf biomass, leaf area, LAI, and epiphyte biomass. Length and width of leaves of shoots were measured allowing the computation of average leaf area per shoot $\left(\mathrm{cm}^{2}\right.$ of leaves shoot $\left.{ }^{-1}\right)$, which were scaled per surface area using $\mathrm{SD}_{M}$ providing an estimate of LAI $\left(\mathrm{m}^{2}\right.$ of leaves $\mathrm{m}^{-2}$ of sediment). The leaves were scraped with a razor blade to collect epiphytes, and naked leaves and epiphytes were dried at $60^{\circ} \mathrm{C}$ for $48 \mathrm{~h}$ before measurements of dry weight (dry wt) with a precision of $\pm 0.001 \mathrm{~g}$. Leaf biomass, epiphyte biomass, and total aboveground biomass per shoot $\left(\mathrm{g}_{\mathrm{dry}}\right.$ wt shoot $^{-1}$ ) were scaled per surface area $\left(\mathrm{g}_{\text {dry wt }} \mathrm{m}^{-2}\right)$ using $\mathrm{SD}_{M}$.

\section{Results}

Water temperatures were homogenous at the three depths, with maximal values $\left(\sim 26^{\circ} \mathrm{C}\right)$ in late summer and minimal values $\left(\sim 13^{\circ} \mathrm{C}\right)$ in late winter (Fig. 3). Wind speeds were generally low, averaging $1.9 \pm 1.3 \mathrm{~m} \mathrm{~s}^{-1}$ for the whole study period, and ranged between 0.2 and $10.0 \mathrm{~m} \mathrm{~s}^{-1}$ (Fig. 3) because the Bay of Revellata is protected from dominant southwest winds. On several occasions (indicated by arrows on Fig. 3), a rapid ( $\sim 1$ d) and intense (as much as $\sim 3^{\circ} \mathrm{C}$ ) decrease of water temperature was observed in conjunction with high wind events, related to the advection of off-shore water into the Bay of Revellata. Minimal annual water temperatures (February-March) were higher by $\sim 1^{\circ} \mathrm{C}$ in $2007\left(14.0^{\circ} \mathrm{C}\right.$ to $\left.14.5^{\circ} \mathrm{C}\right)$ than in 2008 and $2009\left(13.0^{\circ} \mathrm{C}\right.$ to $\left.13.5^{\circ} \mathrm{C}\right)$.

Oxygen saturation levels showed a marked seasonal cycle at the three depths, with $\mathrm{O}_{2}$ oversaturation with respect to atmospheric equilibrium from spring to fall (up to $245 \%$ at $9.5 \mathrm{~m}$ in late February 2009) and $\mathrm{O}_{2}$ saturation or undersaturation (minimal values down to $\sim$ $80 \%$ ) during winter (Fig. 3). The highest $\mathrm{O}_{2}$ saturation levels were observed at $9.5 \mathrm{~m}$ during summer. Whatever the season, a daily variation of $\mathrm{O}_{2}$ concentration was observed following the pattern expected from day-night cycles, which was more marked during summer than during winter and at $9.5 \mathrm{~m}$ than at the other two depths (Fig. 4).

The shoot density at $10 \mathrm{~m}$ averaged $425 \pm 92$ shoots $\mathrm{m}^{-2}$ for the whole sampling period, in close agreement with values previously reported in the area at the same depth (Gobert et al. 2003) and elsewhere in the Mediterranean Sea (Pergent-Martini et al. 1994) and did not show significant seasonal variations (one way analysis of variance, $F=1.125>F_{0.95,6,9}=3.36, p=0.36$ ). Seasonal variations and values of leaf and epiphyte biomass (Fig. 5) followed the patterns previously reported in the area (Bay 1984) and elsewhere in the Mediterranean Sea (Barrón et al. 2006). Leaf biomass increased in spring, was maximal and relatively stable in summer, and decreased in fall due to leaf decay and export out of the meadow with fall and winter storms. The seasonal variations of epiphyte biomass tracked those of leaf biomass (Fig. 5; Table 1) because of the rapid colonization of new substrate (leaf) by epiphytes, in agreement with previous observations of $P$. oceanica (Lepoint et al. 1999). Epiphyte biomass accounted for a maximum of $30 \%$ of total aboveground biomass, in agreement with previous reports in $P$. oceanica meadows (Lepoint et al. 1999). Chl $a$ values never exceeded $2 \mu \mathrm{g} \mathrm{L}^{-1}$, and the seasonal cycle was characterized by a spring bloom (well marked in April 2007), a fall bloom (October 2006, November 2008) and very low values in summer, in agreement with previous observations in the area (Goffart et al. 2002) and elsewhere in the Western Mediterranean Sea (Marty and Chiavérini 2002).

For the whole study period, GPP based on the open water $\mathrm{O}_{2}$ mass balance ranged between 0.4 and $1338.0 \mathrm{mmol}$ $\mathrm{O}_{2} \mathrm{~m}^{-2} \mathrm{~d}^{-1}$, with maximal values in midsummer and minimal values in late fall (Fig. 6). GPP was characterized by strong subweekly variability most probably related to 

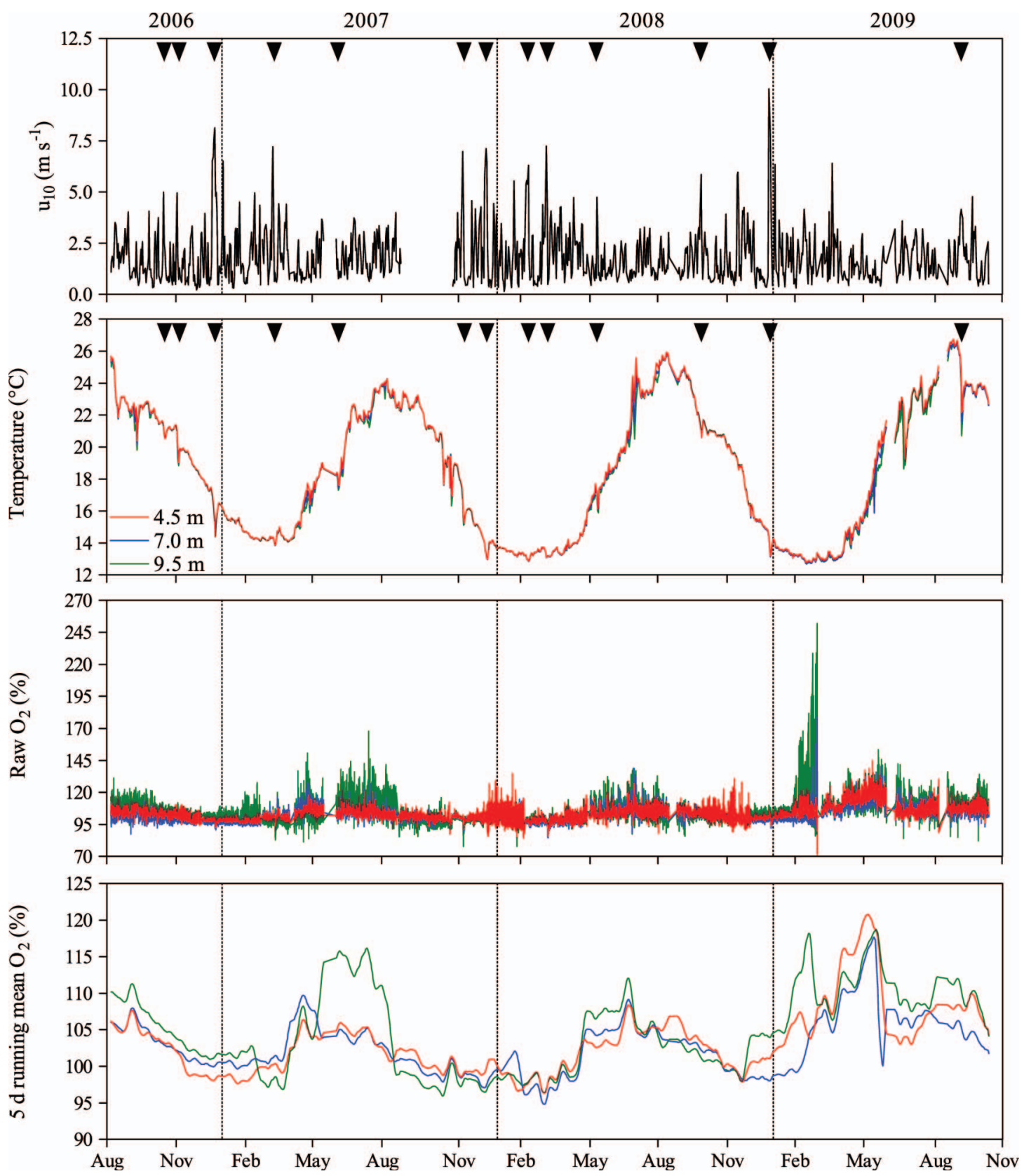

Fig. 3. Time series of daily $\mathrm{u}_{10}\left(\mathrm{~m} \mathrm{~s}^{-1}\right)$, water temperature $\left({ }^{\circ} \mathrm{C}\right)$, raw, and 5 -d running mean of oxygen saturation level $(\%)$ at 4.5 , 7.0, and $9.5 \mathrm{~m}$ from a mooring deployed over a P. oceanica meadow (10-m depth) from 06 August 2006 to 14 October 2009.

day-to-day variability of irradiance. CR variations closely tracked those of GPP. Monthly averages of GPP and CR based on the open water mass balance approach compared well in terms of intensity and seasonality with the GPP and CR values derived from benthic chamber incubations (Fig. 6). NCP showed distinct patterns in 2006-2007 and in 2008-2009. From August 2006 to August 2007, the community was close to metabolic balance $(\mathrm{NCP} \sim 0$ ). From September 2007 to November 2009, NCP showed a seasonal variation that was consistent with the seasonal variation of meadow biomass (Fig. 5), with a more or less steady increase of NCP from October to February-April (when aboveground biomass increased), followed by a more or less steady decrease of NCP throughout summer and fall (when aboveground biomass was stable and then decreased).

\section{Discussion}

Community metabolic rates estimated from open water mass balance of $\mathrm{O}_{2}$ provide an integrated signal of both the pelagic and benthic compartments. Hereafter, we provide several lines of evidence that strongly suggest that the metabolic rates we derived from the open water mass balance of $\mathrm{O}_{2}$ approach are mostly related to the benthic compartment and that in this particular community and at 
Winter

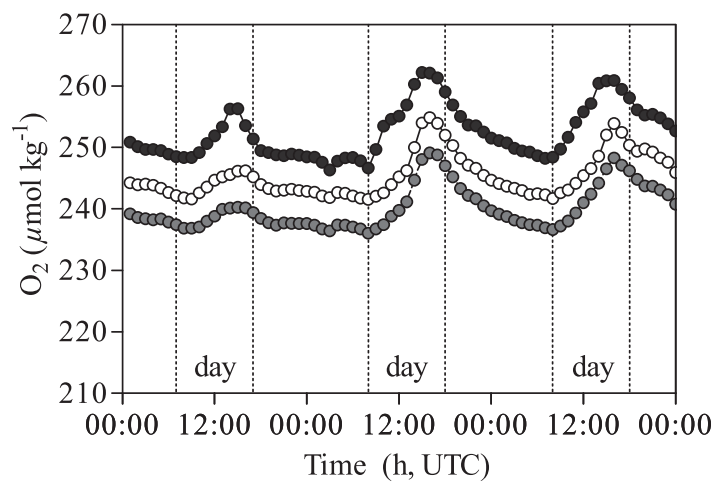

Summer

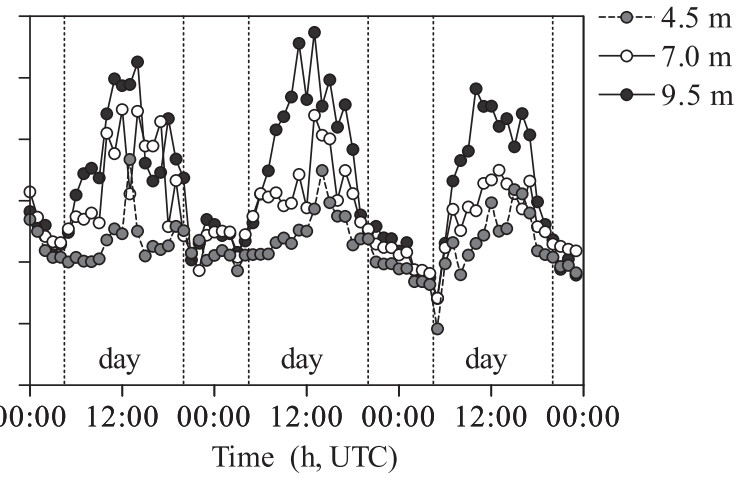

Fig. 4. Time course during $3 \mathrm{~d}$ of oxygen concentration $(\mu \mathrm{mol} \mathrm{kg}-1)$ at $4.5,7.0$, and $9.5 \mathrm{~m}$ from a mooring deployed over a $P$. oceanica meadow (10-m depth) in winter (26-28 January 2008) and summer (15-17 July 2008). UTC, universal time coordinated.

this depth the pelagic compartment is a minor player of community metabolism.

Whatever the season, the amplitude of daily variations of $\mathrm{O}_{2}$ concentration was more marked at $9.5 \mathrm{~m}$ than at the other two depths (Fig. 4), strongly suggesting that $\mathrm{O}_{2}$ was mainly produced and consumed by the $P$. oceanica meadow, and this signal propagated throughout the water column by turbulent diffusion. The yearly maximum of GPP occurred from May to July (Fig. 6), when planktonic Chl $a$ values were particularly low (Fig. 5), and the highest Chl $a$ values were not marked by a distinct increase in GPP. GPP was uncorrelated to planktonic Chl $a$ (Pearson $R=0.07, p=$ $0.052, n=754)$. On the other hand, GPP was strongly correlated with aboveground biomass, LAI, and leaf biomass (Table 1). The strongest correlation of GPP was found with epiphyte biomass. This testifies that epiphyte flora contributed to the benthic community GPP. According to Modigh et al. (1998), epiphyte carbon assimilation ranges between $30 \%$ and $50 \%$ of the total $P$. oceanica shoot production. However, epiphyte biomass also strongly correlated with LAI and leaf biomass; hence, the correlation between GPP and epiphyte biomass also indirectly reflected the contribution of $P$. oceanica to community GPP.

Gazeau et al. (2005b) reported a relationship between pelagic GPP and integrated Chl $a$ during the spring phytoplankton bloom in the Bay of Palma, characterized by the presence of a $P$. oceanica meadow and by Chl $a$ levels similar to those observed in the Bay of Revellata. Pelagic GPP was roughly evaluated from our data set based on this relationship, assuming a vertically homogenous distribution of Chl $a$ at the mooring, and using the fluoromoter data to derive integrated $\mathrm{Chl} a$. For the period
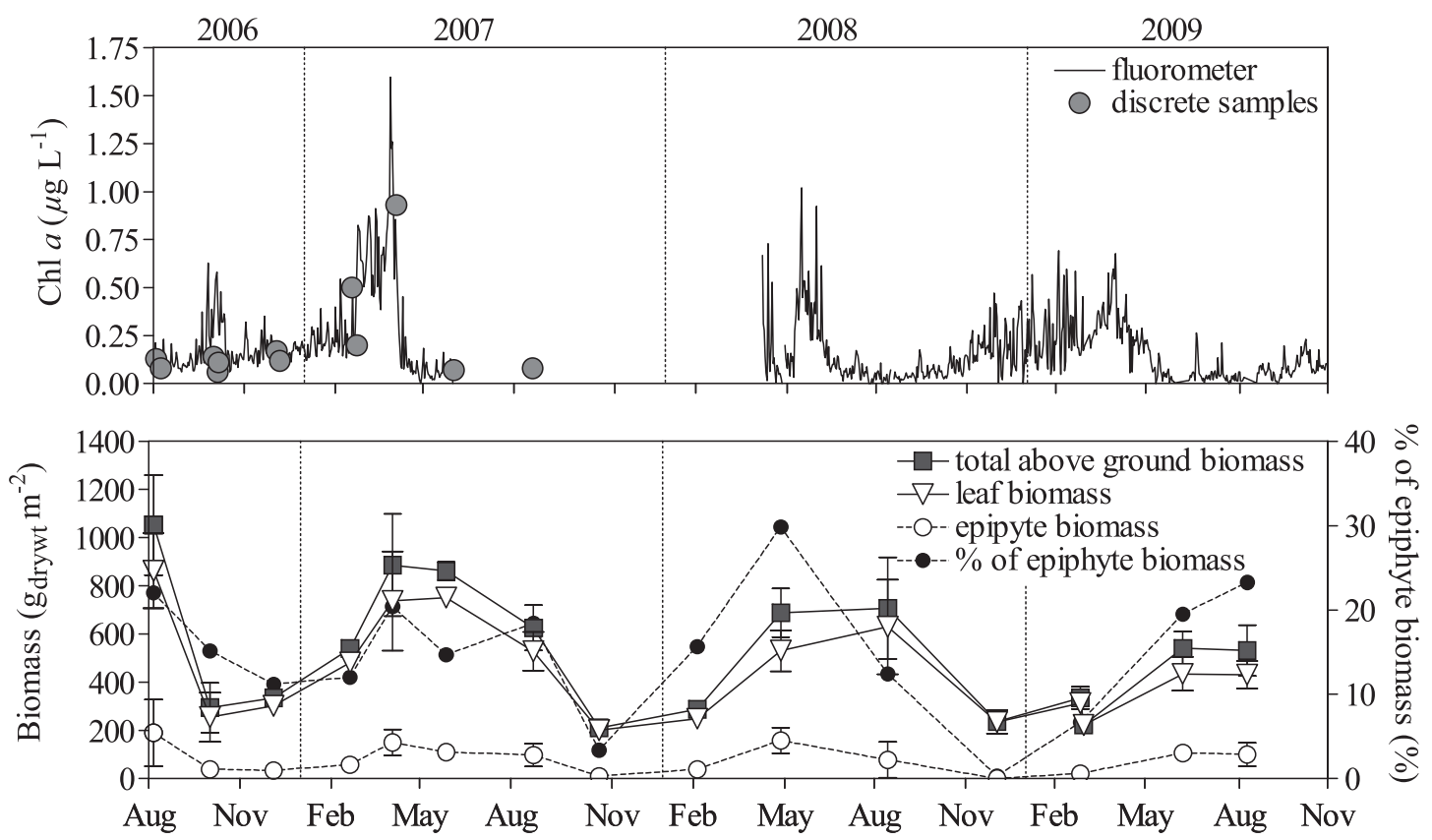

Fig. 5. Times series of $\mathrm{Chl} a\left(\mu \mathrm{g} \mathrm{L}^{-1}\right)$ at $4.5 \mathrm{~m}$ obtained discretely and continuously with a fluorometer, and total aboveground biomass, leaf biomass, epiphyte biomass $\left(\mathrm{g}_{\mathrm{dry} w \mathrm{w}} \mathrm{m}^{-2}\right)$, and contribution of epiphyte biomass to total aboveground biomass $(\%)$ over a $P$. oceanica meadow (10-m depth) from 06 August 2006 to 14 October 2009. 
Table 1. Statistics $(R, p)$ of Pearson regressions between GPP and biometry and among biometry variables based on data acquired over a $P$. oceanica meadow (10-m depth) from 06 August 2006 to 14 October 2009.

\begin{tabular}{llcr}
\hline \hline \multicolumn{1}{c}{$\mathrm{x}$} & \multicolumn{1}{c}{$\mathrm{y}$} & $R$ & $p$ \\
\hline GPP & Total above ground biomass & 0.794 & 0.0088 \\
GPP & Epiphyte biomass & 0.923 & 0.0003 \\
GPP & LAI & 0.770 & 0.0126 \\
GPP & Leaf biomass & 0.760 & 0.0102 \\
Total above ground biomass & LAI & 0.915 & 0.0005 \\
Epiphyte biomass & LAI & 0.891 & 0.0011 \\
Epiphyte biomass & Leaf biomass & 0.874 & $<0.0001$ \\
\hline
\end{tabular}

from 01 August 2006 to 01 August 2007, calculated pelagic GPP ranged from $\sim 0.0$ to $92.6 \mathrm{mmol} \mathrm{O}_{2} \mathrm{~m}^{-2} \mathrm{~d}^{-1}$ and averaged $4.5 \mathrm{~mol} \mathrm{O}_{2} \mathrm{~m}^{-2} \mathrm{yr}^{-1}$. For the same period, community GPP derived from the open water $\mathrm{O}_{2}$ mass balance ranged from 0.4 to $564.6 \mathrm{mmol} \mathrm{O}_{2} \mathrm{~m}^{-2} \mathrm{~d}^{-1}$ and averaged $56.9 \mathrm{~mol} \mathrm{O}_{2} \mathrm{~m}^{-2} \mathrm{yr}^{-1}$. For the period from 01 November 2008 to 01 November 2009, calculated pelagic GPP ranged from $\sim 0.0$ to $40.1 \mathrm{mmol} \mathrm{O}_{2} \mathrm{~m}^{-2} \mathrm{~d}^{-1}$ and averaged $3.5 \mathrm{~mol} \mathrm{O}_{2} \mathrm{~m}^{-2} \mathrm{yr}^{-1}$. For the same period, community GPP ranged from 2.9 to $1338.0 \mathrm{mmol} \mathrm{O}_{2}$ $\mathrm{m}^{-2} \mathrm{~d}^{-1}$ and averaged $94.4 \mathrm{~mol} \mathrm{O}_{2} \mathrm{~m}^{-2} \mathrm{yr}^{-1}$. This suggests that the pelagic compartment contributes $<10 \%$ of community GPP on an annual scale in this specific community at this depth.

In fact, during phytoplankton blooms, benthic community production seemed to decrease, which was probably related to the shading effect of phytoplankton and a subsequent decrease of photosynthesis by $P$. oceanica meadows. This effect seemed to have been well marked during the more intense spring phytoplankton bloom in 2007 (from mid-February to early April; Fig. 5). Average $\mathrm{O}_{2}$ saturation levels at $9.5 \mathrm{~m}$ during the $10 \mathrm{~d}$ prior to the start of the spring phytoplankton in $2007(103.1 \% \pm 1.5 \%)$ were significantly higher than during the first $10 \mathrm{~d}$ of the phytoplankton bloom $(98.3 \% \pm 0.8 \%)$ (Student test, $t_{\mathrm{ob}}=$ $\left.3.98>t_{\text {crit(0.95.9) }}=2.10, p=0.0009\right)$. Also, average $\mathrm{O}_{2}$ saturation levels at $9.5 \mathrm{~m}$ during the last $10 \mathrm{~d}$ of the spring phytoplankton in $2007(96.9 \% \pm 1.9 \%)$ were significantly lower than during the $10 \mathrm{~d}$ after the end of the phytoplankton bloom $(103.0 \% \pm 2.0 \%)\left(t_{\mathrm{ob}}=3.16>\right.$ $\left.t_{\text {crit }(0.95,9)}=2.10, p=0.0054\right)$.

Based on the above considerations, community metabolism in the studied environment can be mainly ascribed to the benthic compartment allowing a direct comparison of metabolic rates derived from the open water $\mathrm{O}_{2}$ mass balance approach and those derived from the benthic incubations. Overall, GPP and CR values derived from benthic incubations are consistent with those derived from the open water $\mathrm{O}_{2}$ mass balance in intensity and seasonality (Fig. 6). However, GPP derived from benthic incubations using chamber design 1 seemed to provide underestimates compared with GPP derived from the open water $\mathrm{O}_{2}$ mass balance (Fig. 7). While the slope of the linear regression was not significantly different from $1\left(t_{\mathrm{ob}}=0.837<t_{\text {crit }}=\right.$ $2.36)$, the $Y$-intercept was significantly different from 0 $\left(t_{\mathrm{ob}}=2.40>t_{\text {crit }}=2.36\right)$. Values of $\mathrm{CR}$ from benthic incubations using chamber design 1 and those derived from the open water $\mathrm{O}_{2}$ mass balance were not statistically different, since the slope of the linear regression was not significantly different from $1\left(t_{\mathrm{ob}}=0.169<t_{\text {crit }}=2.36\right)$ and the Y-intercept was not significantly different from 0 $\left(t_{\mathrm{ob}}=1.36<t_{\text {crit }}=2.36\right)$.

One possible explanation for the lower GPP values by benthic chamber incubations compared with the open water $\mathrm{O}_{2}$ mass balance could be related to the fact that rhizomes and roots of $P$. oceanica were cut by the PVC base of the benthic chambers. While we cannot quantify the stress of $P$. oceanica caused by this based on available data, there are several reasons to suppose it was marginal. Assimilation of nutrients by $P$. oceanica is mainly made by leaves from the water column rather than from sediment by roots (Alcoverro et al. 2000). The main role of roots and rhizomes is anchoring in the sediment (Meinesz et al. 1991). The physiological role of rhizomes is resource translocation between shoots mainly toward the apex of the rhizome (Marbà et al. 2002), usually corresponding to young growing shoots in the periphery of meadows. Our benthic incubations were made in the mature and dense part of the meadow away from the periphery of the meadow. In mature and dense regions of the meadow, there is a prevalence or even complete dominance of orthotropic (vertical) compared with plagiotropic (horizontal) rhizomes (Meinesz et al. 1991). Hence, the insertion of the PVC base into the sediment most probably spared the dominant plagiotropic rhizomes.

We identified two additional possible reasons for the underestimation of GPP by benthic chambers of design 1 compared with the open water $\mathrm{O}_{2}$ mass balance. First, in the confined chamber environment, there could be an increase of $\mathrm{pH}$ and $\mathrm{O}_{2}$ during the daytime that in conjunction with high irradiance leads to photorespiration when the enzyme Ribulose-1,5 bisphosphate-carboxylaseoxygenase switches from carboxylase to oxygenase (Heber et al. 1996). Under these conditions, there is a consumption of $\mathrm{O}_{2}$ and a release of $\mathrm{CO}_{2}$, leading to an underestimation of GPP estimated from the change in $\mathrm{O}_{2}$. Second, this effect could have been enhanced in a relatively motionless environment leading to the thickening of the molecular diffusion boundary layer between the $P$. oceanica leaves and water, since there was little stirring of water in benthic chambers of design 1 (water pump was only used a few minutes prior to each sampling).

To check these sources of underestimation of GPP estimated from benthic chamber incubations, we carried 

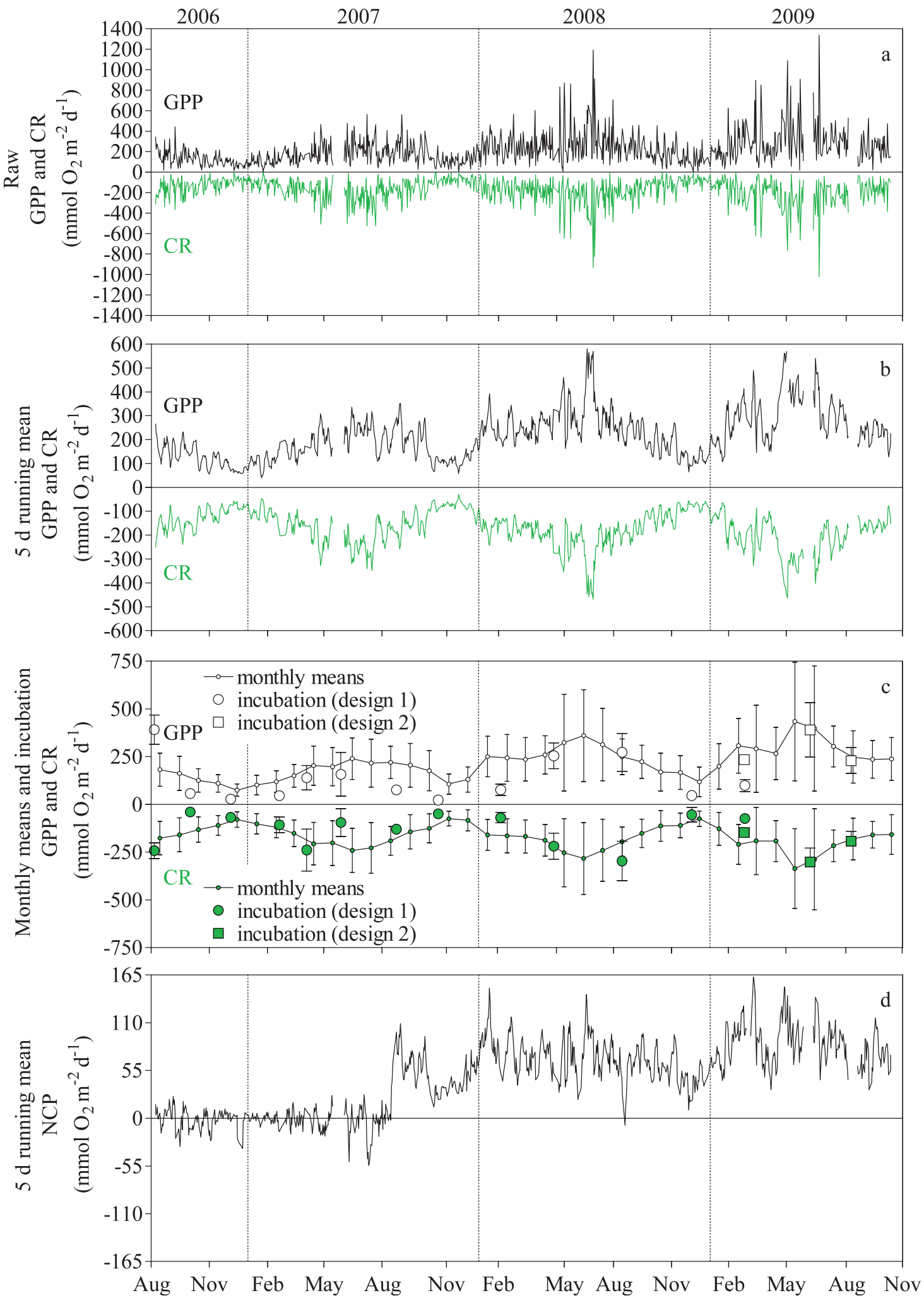

Fig. 6. GPP and CR shown as (a) raw data, (b) 5-d running means, and (c) monthly averages derived from the open water $\mathrm{O}_{2}$ mass balance. Error bars show standard deviation on the monthly mean. Overlaid in (c) are mean GPP and CR derived from the diel change of $\mathrm{O}_{2}$ in benthic chamber incubations over a $P$. oceanica meadow (10-m depth) from 06 August 2006 to 14 October 2009 . Error bars show the standard deviation on the means of rates from three incubations and provide information regarding the small scale spatial variability. (d) Five-day running mean of NCP derived from the open water $\mathrm{O}_{2}$ mass balance. 


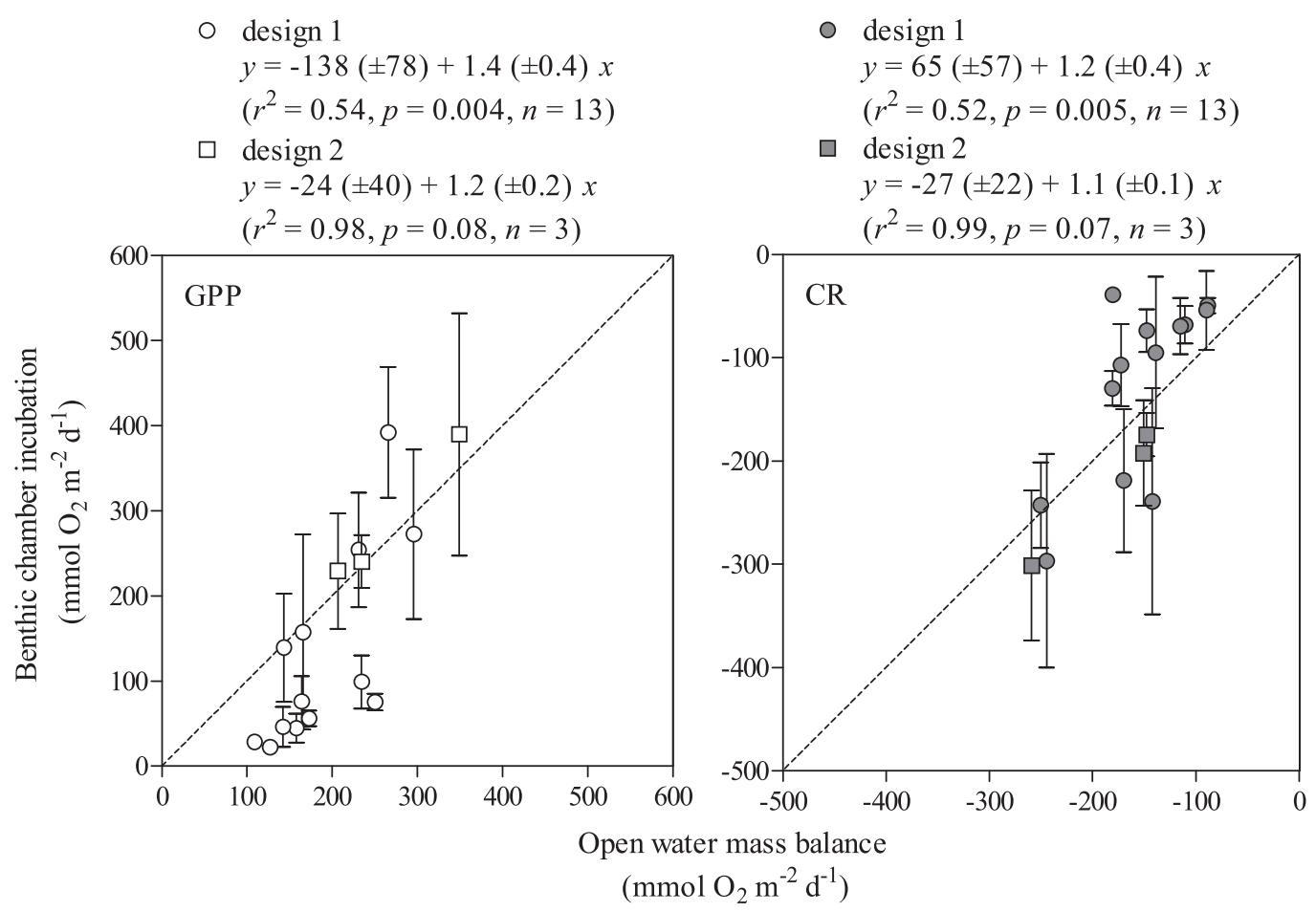

Fig. 7. Comparison of GPP and $\mathrm{CR}\left(\mathrm{mmol} \mathrm{O}_{2} \mathrm{~m}^{-2} \mathrm{~d}^{-1}\right)$ derived from diel change of $\mathrm{O}_{2}$ in benthic chamber incubations and from open water $\mathrm{O}_{2}$ mass balance over a $P$. oceanica meadow (10-m depth) from 06 August 2006 to 14 October 2009.

out two sets of experiments. On 28-29 April 2008, an incubation was carried out with a $\mathrm{O}_{2}$ optode inside the benthic chamber. During daytime, $\mathrm{O}_{2}$ saturation levels ranged between $160 \%$ and $180 \%$ during a period of $\sim 5 \mathrm{~h}$. $\mathrm{pH}$ was sampled during the same incubation at maximum of irradiance and was $\sim 8.2$, below the threshold value of 8.5 , above which primary production by $P$. oceanica starts to decrease according to Invers et al. (1997). This would suggest that if photorespiration occurred during the benthic chamber incubations, it was related to an increase of $\mathrm{O}_{2}$ rather than an increase of $\mathrm{pH}$, although it cannot be excluded that $\mathrm{pH}$ was much higher in the molecular diffusion boundary layer between the $P$. oceanica leaves and water.

From February 2009 onward, the design of the chambers was modified (design 2, Fig. 2) to increase the incubated volume by 8 liters so as to reduce the levels of $\mathrm{O}_{2}$ accumulation during daytime, and incubated water was mixed during the whole cycle with the water pump so as to avoid the thickening of the molecular diffusion boundary layer between the $P$. oceanica leaves and water. On 24-25 February 2009, four benthic incubations were run with chamber design 1 and design 2 in parallel (each in duplicate). GPP derived from benthic incubations averaged $99 \pm 22 \mathrm{mmol} \mathrm{O}_{2} \mathrm{~m}^{-2} \mathrm{~d}^{-1}$ and $240 \pm 31 \mathrm{mmol} \mathrm{O}_{2}$ $\mathrm{m}^{-2} \mathrm{~d}^{-1}$ for designs 1 and 2, respectively. GPP derived from open water $\mathrm{O}_{2}$ mass balance during this experiment was $235 \mathrm{mmol} \mathrm{O}_{2} \mathrm{~m}^{-2} \mathrm{~d}^{-1}$. The GPP values subsequently derived from benthic incubations using design 2 in June and August 2009 also compared very satisfactorily with GPP derived from the open water $\mathrm{O}_{2}$ mass balance (Fig. 7).
GPP was characterized by strong subweekly variability most probably related to day-to-day variability of irradiance (Fig. 6). Indeed, $P$. oceanica efficiently recycles nutrients by internal translocation (Alcoverro et al. 2000), and primary production and growth are mainly limited by light availability (Alcoverro et al. 1995). Strong day-to-day variability of NCP significantly correlated to irradiance over a $P$. oceanica meadow in the Bay of Palma was reported over a 10-d period (Gazeau et al. 2005b).

CR variations closely tracked those of GPP (Fig. 6), indicating a close coupling of heterotrophic and/or autotrophic respiration with GPP. Autotrophic respiration is coupled to GPP across phototrophic organisms including macrophytes (Enríquez et al. 1996). A large fraction of the $P$. oceanica community production is exudated as dissolved organic carbon (DOC) to the water column $(\sim 70 \%$ of NCP, Barrón and Duarte 2009) and possibly to the sediments through roots. It is expected that DOC exudation increases with GPP; hence, it can be expected that heterotrophic respiration will respond quickly to an increase of GPP. In C. nodosa meadows, Barrón et al. (2004) highlighted a strong correlation between CR and DOC exudation. Strong correlations between GPP and CR have been previously reported in $P$. oceanica meadows (Barrón et al. 2006). These have also been reported in the algal-dominated community in the Biosphere II reef mesocosm at timescales of days to weeks (Falter et al. 2001) and in an algal-dominated reef flat (Falter et al. 2011). GPP and CR have also been reported to be closely correlated across the different benthic communities within a given system (Santos et al. 2004). Finally, GPP and CR 
Table 2. Annually integrated GPP, CR, and NCP $\left(\mathrm{mol} \mathrm{O}_{2} \mathrm{~m}^{-2} \mathrm{yr}^{-1}\right)$ and $\mathrm{P}: \mathrm{R}$ for 2006-2007, 2007-2008, and 2008-2009 derived from the open water $\mathrm{O}_{2}$ mass balance and derived from the diel change of $\mathrm{O}_{2}$ in benthic chamber incubations over a $P$. oceanica meadow (10-m depth) from 06 August 2006 to 14 October 2009. Owing to bad weather conditions, benthic incubations were not carried during the November 2009 cruise, and it was not possible to provide a yearly budget of metabolic rates for the 2008-2009 yearly cycle.

\begin{tabular}{lccr}
\hline \hline & 2006-2007 & 2007-2008 & 2008-2009 \\
\hline Open water mass balance & & & \\
$\mathrm{GPP}\left(\mathrm{mol} \mathrm{O}_{2} \mathrm{~m}^{-2} \mathrm{yr}^{-1}\right)$ & $61.3 \pm 0.6$ & $88.8 \pm 0.9$ & $96.0 \pm 1.0$ \\
$\mathrm{CR}\left(\mathrm{mol} \mathrm{O}_{2} \mathrm{~m}^{-2} \mathrm{yr}^{-1}\right)$ & $-57.7 \pm 0.6$ & $-64.2 \pm 0.6$ & $-67.2 \pm 0.7$ \\
$\mathrm{NCP}\left(\mathrm{mol} \mathrm{O}_{2} \mathrm{~m}^{-2} \mathrm{yr}^{-1}\right)$ & $3.5 \pm 0.8$ & $24.6 \pm 1.1$ & $28.8 \pm 1.2$ \\
$\mathrm{P}: \mathrm{R}$ & 1.06 & 1.38 & 1.43 \\
Benthic chamber incubations & & & \\
$\mathrm{GPP}\left(\mathrm{mol} \mathrm{O} \mathrm{m}^{-2} \mathrm{yr}^{-1}\right)$ & $29.2 \pm 6.4$ & $64.3 \pm 14.0$ & - \\
$\mathrm{CR}\left(\mathrm{mol} \mathrm{O}_{2} \mathrm{~m}^{-2} \mathrm{yr}^{-1}\right)$ & $-39.9 \pm 8.8$ & $-64.6 \pm 14.0$ & - \\
$\mathrm{NCP}\left(\mathrm{mol} \mathrm{O}_{2} \mathrm{~m}^{-2} \mathrm{yr}^{-1}\right)$ & $-10.7 \pm 10.9$ & $-0.3 \pm 19.8$ & - \\
$\mathrm{P}: \mathrm{R}$ & 0.75 & 1.00 & - \\
\hline
\end{tabular}
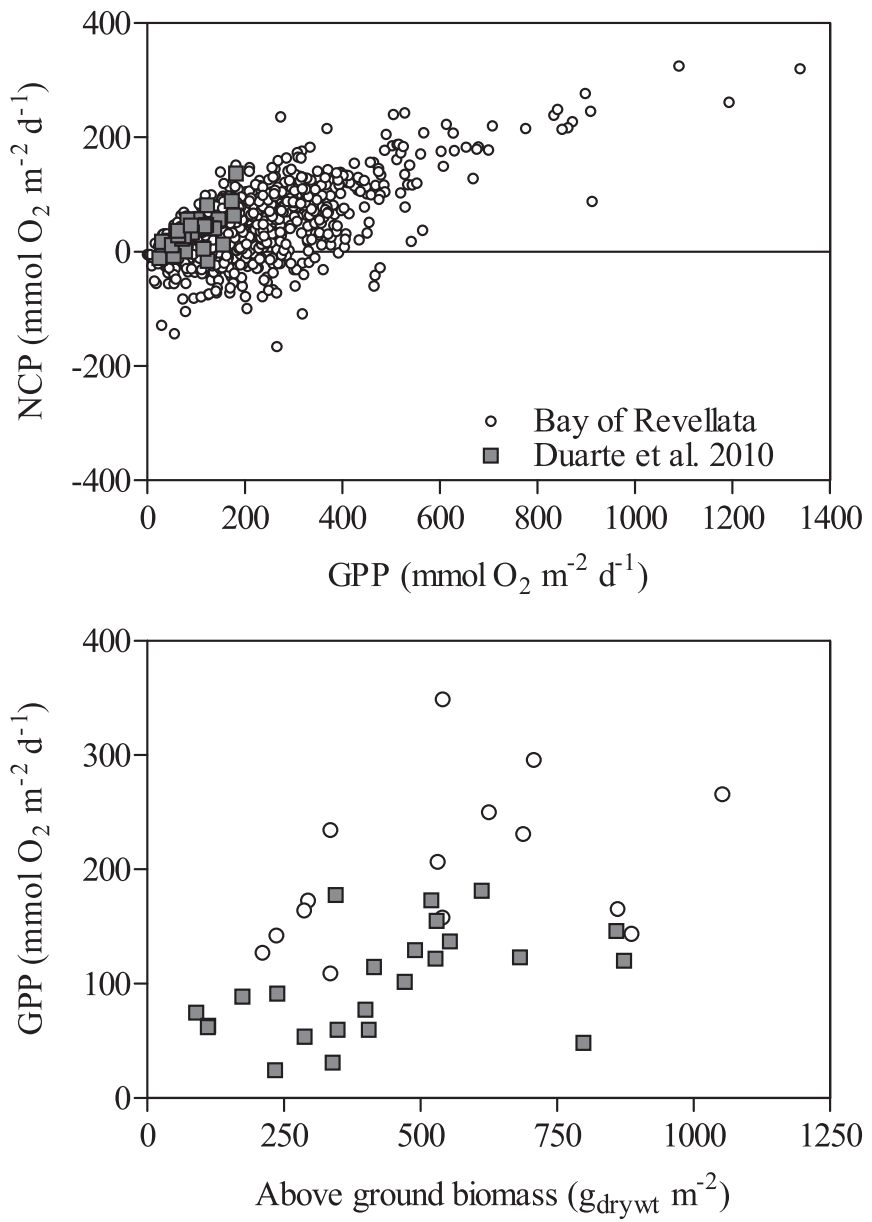

Fig. 8. Comparison of NCP vs. GPP $\left(\mathrm{mmol} \mathrm{O}_{2} \mathrm{~m}^{-2} \mathrm{~d}^{-1}\right)$ and GPP vs. aboveground biomass $\left(\mathrm{g}_{\mathrm{dry}} \mathrm{wt} \mathrm{m}^{-2}\right)$ obtained by open water $\mathrm{O}_{2}$ mass balance over a $P$. oceanica meadow (10-m depth) from 06 August 2006 to 14 October 2009 in the Bay of Revelatta and compiled by Duarte et al. (2010) in other P. oceanica meadows mainly from Mallorca Island (Holmer et al. 2004; Barrón et al. 2006; Gazeau et al. 2005b) and Sounion (Apostolaki et al. 2010a). closely correlate across different macrophyte communities (Binzer et al. 2006; Duarte et al. 2010).

Community metabolic rates were integrated annually, considering an annual cycle starting on 01 November and ending on 31 October the following year, since the lowest yearly canopy biomass and community GPP were observed in October-November (Figs. 5, 6). Annually integrated GPP and CR (Table 2) were of the same order of magnitude as those previously reported in $P$. oceanica meadows in Magalluf Bay (Barrón et al. 2006) and Sounion (Apostolaki et al. 2010a). A comparison with GPP from the pelagic compartment in the open Western Mediterranean can be made from data in the Ligurian Sea about $\sim 120 \mathrm{~km}$ north of our study site reported by Marty and Chiavérini (2002) with ${ }^{14} \mathrm{C}$ derived measurements during $4 \mathrm{~h}$ that should provide a reasonable estimate of GPP (Peterson 1980). For the 1993-1999 period, annually integrated pelagic GPP in the Ligurian Sea averaged $16.9 \mathrm{~mol} \mathrm{O}_{2}$ $\mathrm{m}^{-2} \mathrm{yr}^{-1}$ and ranged from 9.3 to $25.3 \mathrm{~mol} \mathrm{O}_{2} \mathrm{yr}^{-1}$ (converted from carbon units using the Redfield $\mathrm{O}_{2}$ :C ratio of $138: 106)$. For the $2007-2009$ period, community GPP over the $P$. oceanica meadow in the Bay of Revellata averaged $82.1 \mathrm{~mol} \mathrm{O}_{2} \mathrm{~m}^{-2} \mathrm{yr}^{-1}, \sim 80 \%$ higher than in the open Ligurian Sea, confirming that $P$. oceanica are major primary producers in the Mediterranean Sea (Gazeau et al. 2005b).

Values derived from benthic chamber incubations provided a negative NCP (net heterotrophic community). As discussed above, incubations using chamber design 1 probably provided underestimates of GPP as a result of photorespiration while not affecting CR significantly. The open water $\mathrm{O}_{2}$ mass balance approach most probably provided more realistic GPP values. Based on the community metabolic rates derived from open water $\mathrm{O}_{2}$ mass balance approach, the community was net autotrophic at an annual scale $(\mathrm{NCP}>0)$ in agreement with previous studies based on incubation rate measurements (Frankignoulle and Bouquegneau 1987; Gazeau et al. 2005b; Barrón et al. 2006; Apostolaki et al. 2010a), mass 

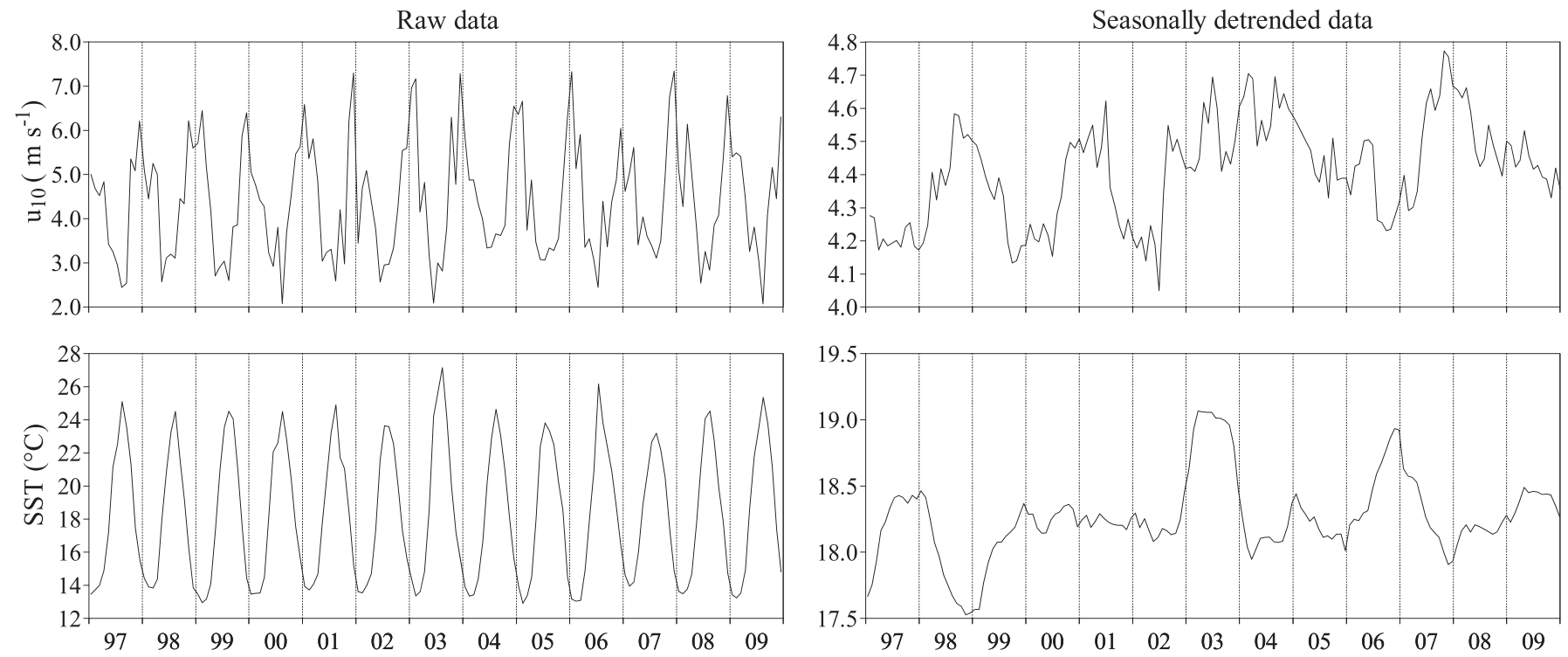

Fig. 9. Time series from 1997 to 2009 of monthly average and seasonally detrended $\mathrm{u}_{10}\left(\mathrm{~m} \mathrm{~s}^{-1}\right.$, National Centers for Environmental Prediction Reanalysis-1 [http://www.cdc.noaa.gov/] at $9.3750^{\circ} \mathrm{E} 42.8564^{\circ} \mathrm{N}$ ) and sea surface temperature $\left(\mathrm{SST},{ }^{\circ} \mathrm{C}\right.$, Reynolds climatology [Reyn SmithOIv2, http://iridl.ldeo.columbia.edu/] in $\left.\left[8.0^{\circ} \mathrm{E} 8.5^{\circ} 5 ; 42.0^{\circ} \mathrm{N} 43.0^{\circ} \mathrm{N}\right]\right)$. Signals were seasonally detrended using a 1 -yr lowpass filter. Note the different scales of $\mathrm{Y}$-axis on left and right panels.

balance considerations, and net carbon accumulation in P. oceanica (Mateo et al. 1997; Duarte et al. 2010).

The comparison of our data set with available data of community metabolic rates in $P$. oceanica meadows compiled by Duarte et al. (2010) shows a consistent positive pattern of GPP with aboveground biomass and a consistent positive pattern of NCP with GPP (Fig. 8). Our data set considerably expands the range of variation of NCP and GPP previously reported in $P$. oceanica meadows (Fig. 8). The highest values of GPP we report $(1338.0 \mathrm{mmol}$ $\mathrm{O}_{2} \mathrm{~m}^{-2} \mathrm{~d}^{-1}$ ) are close to the highest values ever reported before in seagrass meadows of $1296.9 \mathrm{mmol} \mathrm{O}_{2} \mathrm{~m}^{-2} \mathrm{~d}^{-1}$ in a Halodule wrightii meadow in Bojorquez Lagoon, Mexico (Reyes and Merino 1991). This could be related to the fact that extreme GPP values in $P$. oceanica meadows are rare events that are difficult to capture with classical incubation methods that are typically at a monthly scale. In our data set, GPP values $>400 \mathrm{mmol} \mathrm{O} \mathrm{m}^{-2} \mathrm{~d}^{-1}$ correspond to $\sim 8 \%$ of all observations, $>600 \mathrm{mmol} \mathrm{O}_{2} \mathrm{~m}^{-2} \mathrm{~d}^{-1}$ correspond to $\sim 2 \%$ of all observations, and $>800 \mathrm{mmol}$ $\mathrm{O}_{2} \mathrm{~m}^{-2} \mathrm{~d}^{-1}$ correspond to $\sim 1 \%$ of all observations. Further, during high GPP events, intense $\mathrm{O}_{2}$ accumulation could induce photorespiration and lead to an underestimation of GPP derived from benthic chamber incubations, as revealed by the present work. This could also explain that GPP values derived from open water $\mathrm{O}_{2}$ mass balance from our data set for a given aboveground biomass value tend to be higher than those reported by Duarte et al. (2010) for $P$. oceanica derived from benthic chambers (Fig. 8; Y-intercepts of the linear regressions of both data sets are significantly different; $t_{\mathrm{ob}}=2.40>t_{\text {crit }}=2.36$ ).

Community metabolic rates showed strong interannual variations with GPP and NCP values distinctly lower in 2006-2007 than in 2007-2008 and 2008-2009 (Table 2). The GPP : |CR| (P:R) ratio was distinctly lower in 2006
2007 than during the other two yearly cycles, implying that in addition to a decrease of GPP, the relative importance of CR to GPP was higher in 2006-2007 (one can theoretically envisage a situation where environmental factors induce a decrease of GPP while not changing the $\mathrm{P}: \mathrm{R}$ ratio, leading to little change in NCP absolute values). Water temperature during the winter of 20062007 was the highest during the study period and the $10 \mathrm{yr}$ prior to the start of the study period (Fig. 9), due to the exceptionally mild 2006-2007 winter across Europe (Luterbacher et al. 2007). The winter of 2006-2007 was also characterized by lower wind speeds compared with winters of 2007-2008 and 2008-2009 and compared with the 10 -yr period prior to the start of the study period, with three exceptions (1997-1998, 1999-2000, 2001-2002) (Fig. 9). After the decay of $P$. oceanica leaves in late summer and early fall, they are usually exported out of the meadow by the fall and winter storms. During the winter of 2006-2007 the export of dead leaves did not occur due to lower wintertime wind speeds. From fall 2006 to August 2007, dead leaves accumulated as litter in the $P$. oceanica meadow as observed during the scuba dives around the mooring (on October, December, and February 2006; April, May, and August 2007). In late September 2007, a 3 -day storm probably cleared the accumulated litter from the meadow, and at this period an increase of NCP was observed (Fig. 6). During the scuba dives in late October 2007, visual inspection confirmed that litter had been exported from the meadow. We hypothesize that the lower values of P : R ratio, GPP, and NCP in 2006-2007 than the other two yearly cycles were related to the accumulation of litter in the meadow due to lower wintertime wind speeds and not necessarily related to the higher wintertime temperatures. The higher wintertime temperatures in 2006-2007 would be expected to have a minimal effect 
on annual $\mathrm{P}: \mathrm{R}$ ratio and $\mathrm{NCP}$ since GPP and $\mathrm{CR}$ were low during winter anyway. The accumulated litter in the meadow probably fueled CR and contributed to decreased $\mathrm{P}: \mathrm{R}$. While the leaf biomass data (Fig. 5) did not reveal marked differences among years, the presence of litter on the meadow might also have decreased community GPP by the shading effect on rhizome epiphytic and benthic macroalgae and microalgae associated with the $P$. oceanica meadow. Unlike other seagrasses, $P$. oceanica is characterized by greater species richness and higher biomass of epiphytes on the exposed rhizomes compared with leaves (Borowitzka et al. 2006).

Seagrass meadows are threatened by a variety of direct and indirect human pressures (Waycott et al. 2009). Direct threats include clearing of meadows due to shoreline constructions, mechanical damage (dredging and anchoring), eutrophication, and siltation, the latter two leading to light limitation. Among indirect threats, water temperature increase has been shown to modify $P$. oceanica physiology (induction of flowering by thermal stress; Diáz-Almela et al. 2007) and meadow dynamics (increase of shoot mortality and decrease of recruitment, Marbà and Duarte 2010). Here, we highlight another potential future modification of $P$. oceanica dynamics with global change, based on the comparison of $3 \mathrm{yr}$ of community metabolic data. The analysis of interannual variations can be used as a natural laboratory to determine how marine communities might respond to future changes of climate forcing. It is predicted that in the future there will be a decrease in frequency and intensity of marine storms in the Mediterranean Sea due to a northward shift of the Atlantic storm track (Lionello et al. 2008). This will modify the carbon flows in $P$. oceanica meadows, which are expected to export less matter to adjacent communities and possibly a decrease of GPP and NCP within the meadows themselves.

The very first primary production measurements were carried out based on oxygen changes in the early 1910s. The diel changes in $\mathrm{O}_{2}$ have been frequently used to estimate metabolic rates based on the Odum (1956) approach in open ocean (Karl et al. 2003) and in coastal environments (Caffrey 2004), including seagrass meadows such as Thalassia testudinum (Odum 1963), Zostera marina (Caffrey 2004), and H. wrightii (Reyes and Merino 1991). The advent of optical sensors to measure $\mathrm{O}_{2}$, such as optodes (Tengberg et al. 2006), opens the possibly of measuring metabolic rates by $\mathrm{O}_{2}$ mass balance robustly, relatively easily, and during long deployments, as demonstrated by the present study. The use of moorings with optodes could provide an affordable and easy tool to monitor the health or degradation of $P$. oceanica communities, since it allows derivation of metabolic rates at the community level while other phenological, biogeochemical, and demographic indicators used so far to evaluate $P$. oceanica status only provide information at the individual or population level (Apostolaki et al. 2010b).

\section{Acknowledgments}

We thank L.-S. Schiettecatte for help in sampling during the first year of the experiment; B. Delille for help in implementing the mooring; P. Lejeune and the Stareso team for logistic support; S. Gobert, G. Lepoint, J. Jacquemart, M.-V. Commarieu, and M.K. Živadinović for assistance during scuba dives; R. Biondo for servicing the benthic chambers; Laboratoire d'Océanologie of the University of Liège for access to sampling and part of analytical equipment; A. Alvera for help with detrending of time series; G. Lepoint and F. Darchambeau for comments during manuscript elaboration; and A.W.D. Larkum and two anonymous reviewers for constructive comments on a previous version of the paper. This work was funded by the Fonds National de la Recherche Scientifique (FNRS) (Mandat d'Impulsion Scientifique F.4513.06, Fonds de la Recherche Fondamentale Collective 2.4.511.09 and 2.4.637.10). A.V.B. is co-first author and a research associate at the FNRS.

\section{References}

Alcoverro, T., C. M. Duarte, and J. Romero. 1995. Annual growth dynamics of Posidonia oceanica: Contribution of large-scale versus local factors to seasonality. Mar. Ecol. Prog. Ser. 120: 203-210, doi:10.3354/meps 120203

- M. Manzanera, AND J. Romero. 2000. Nutrient mass balance of the seagrass Posidonia oceanica: The importance of nutrient retranslocation. Mar. Ecol. Prog. Ser. 194: 13-21, doi:10.3354/meps194013

Apostolaki, E. T., M. Holmer, N. Marbà, and I. Karakassis. 2010a. Metabolic imbalance in coastal vegetated (Posidonia oceanica) and unvegetated benthic ecosystems. Ecosystems 13: 459-471, doi:10.1007/s10021-010-9330-9

$2010 b$. Degrading seagras osidonia oceanica) ecosystems: A source of dissolved matter in the Mediterranean. Hydrobiologia 49: 13-23, doi:10.1007/ s10750-010-0255-2

Barrón, C., and C. M. Duarte. 2009. Dissolved organic matter release in a Posidonia oceanica meadow. Mar. Ecol. Prog. Ser. 374: 75-84, doi:10.3354/meps07715

, M. Frankignoulle, and A. V. Borges. 2006. Organic carbon metabolism and carbonate dynamics in a Mediterranean seagrass (Posidonia oceanica) meadow. Estuar. Coast. 29: 417-426.

, N. Marbà, J. Terrados, H. Kennedy, and C. M DuARTE. 2004. Community metabolism and carbon budget along a gradient of seagrass (Cymodocea nodosa) colonization. Limnol. Oceanogr. 49: 1642-1651, doi:10.4319/ 10.2004.49.5.1642

BAY, D. 1984. A field study of growth dynamics and productivity of Posidonia oceanica (L.) Delile in Calvi Bay, Corsica. Aquat. Bot. 20: 43-64, doi:10.1016/0304-3770(84)90026-3

Benson, B. B., and D. Krause, Jr. 1984. The concentration and isotopic fractionation of oxygen dissolved in freshwater and seawater in equilibrium with the atmosphere. Limnol. Oceanogr. 29: 620-632, doi:10.4319/lo.1984.29.3.0620

Binzer, T., K. Sand-Jensen, and A.-L. Middelboe. 2006. Community photosynthesis of aquatic macrophytes. Limnol. Oceanogr. 51: 2722-2733, doi:10.4319/lo.2006.51.6. 2722

Borowitzka, M. A., P. S. Lavery, and M. Van Keulen. 2006. Epiphytes of seagrasses, p. 463-501. In A. W. D. Larkum, R. J. Orth, and C. M. Duarte [eds.], Seagrasses: Biology, ecology and conservation. Springer.

Boudouresque, C. F. 2004. Marine biodiversity in the Mediterranean: Status of species, populations and communities. Sci. Rep. Port-Cros Natl. Park 20: 97-146.

CAfFrey, J. M. 2004. Factors controlling net ecosystem metabolism in U.S. estuaries. Estuaries 27: 90-101, doi:10.1007/ BF02803563 
Costanza, R., and others. 1997. The value of the world's ecosystem services and natural capital. Nature 387: 253-260, doi: $10.1038 / 387253 \mathrm{a} 0$

Diáz-Almela, E., N. Marbà, and C. M. Duarte. 2007. Consequences of Mediterranean warming events in seagrass (Posidonia oceanica) flowering records. Glob. Change Biol. 13: 224-235, doi:10.1111/j.1365-2486.2006.01260.x

Duarte, C. M., N. Marbà, E. Gacia, J. W. Fourqurean, J. Beggins, C. Barrón, And E. T. Apostolaki. 2010. Seagrass community metabolism: Assessing the carbon sink capacity of seagrass meadows. Glob. Biogeochem. Cycles 24: GB4032, doi:10.1029/2010GB003793

Enríquez, S., S. L. Nielsen, C. M. Duarte, and K. Sand-Jensen. 1996. Broad-scale comparison of photosynthetic rates across phototrophic organisms. Oecologia 108: 197-206.

Falter, J. L., M. J. Atkinson, and C. Langdon. 2001. Production-respiration relationships at different time-scales within the biosphere 2 coral reef biome. Limnol. Oceanogr. 46: 1653-1660, doi:10.4319/lo.2001.46.7.1653

- - - D. W. Schar, R. J. Lowe, and S. G. Monismith. 2011. Short-term coherency between gross primary production and community respiration in an algal-dominated reef flat. Coral Reefs 30: 53-58, doi:10.1007/s00338-010-0671-9

Frankignoulle, M., and J.-M. Bouquegneau. 1987. Seasonal variations of the diel carbon budget of a marine macrophytes ecosystem. Mar. Ecol. Prog. Ser. 38: 197-199, doi:10.3354/ meps038197

Gazeau, F., AND Others. 2005a. Net ecosystem metabolism in a micro-tidal estuary (Randers Fjord, Denmark): Evaluation of methods. Mar. Ecol. Prog. Ser. 301: 23-41, doi:10.3354/ meps301023

- AND OTHERs. 2005b. Whole-system metabolism and $\mathrm{CO}_{2}$ fluxes in a Mediterranean Bay dominated by seagrass beds (Palma Bay, NW Mediterranean). Biogeosciences 2: 43-60, doi:10.5194/bg-2-43-2005

Gobert, S., M. Kyramarios, G. Lepoint, C. Pergent-Martini, AND J.-M. Bouquegneau. 2003. Variations at different spatial scales of Posidonia oceanica (L.) Delile beds; effects on the physico-chemical parameters of the sediment. Oceanol. Acta 26: 199-207, doi:10.1016/S0399-1784(02) 00009-9

Goffart, A., J. H. HecQ, And L. Legendre. 2002. Changes in the development of the winter-spring phytoplankton bloom in the Bay of Calvi (NW Mediterranean) over the last two decades: A response to changing climate? Mar. Ecol. Prog. Ser. 236: 45-60, doi:10.3354/meps236045

Gypens, N., A. V. Borges, and C. Lancelot. 2009. Effect of eutrophication on air-sea $\mathrm{CO}_{2}$ fluxes in the coastal Southern North Sea: A model study of the past 50 years. Glob. Change Biol. 15: 1040-1056, doi:10.1111/j.1365-2486.2008. 01773.x

Heber, U., R. Bligny, P. Streb, and R. Douce. 1996. Photorespiration is essential for the protection of the photosynthetic apparatus of $\mathrm{C} 3$ plants against photoinactivation under sunlight. Bot. Acta 109: 307-315.

Heck, K. L., T. J. B. Carruthers, C. M. Duarte, A. R. Hughes, G. Kendrick, R. J. Orth, and S. W. Williams. 2008. Trophic transfers from seagrass meadows subsidize diverse marine and terrestrial consumers. Ecosystems 11: 1198-1210, doi:10.1007/ s10021-008-9155-y

Ho, D. T., C. S. Law, M. J. Smith, P. Schlosser, M. Harvey, and P. Hill. 2006. Measurements of air-sea gas exchange at high wind speeds in the Southern Ocean: Implications for global parameterizations. Geophys. Res. Lett. 33: L16611, doi:10. 1029/2006GL026817
Holmer, M., C. M. Duarte, H. T. S. Boschker, and C. Barrón 2004. Carbon cycling and bacterial carbon sources in pristine and impacted Mediterranean seagrass sediments. Aquat. Microb. Ecol. 36: 227-237, doi:10.3354/ame036227

Invers, O., J. Romero, And M. Pérez. 1997. Effects of pH on seagrass photosynthesis: A laboratory and field assessment. Aquat. Bot. 59: 185-194, doi:10.1016/S03043770(97)00072-7

Johnson, H. K. 1999. Simple expressions for correcting wind speed data for elevation. Coast. Eng. 88: 101-112.

Karl, D. M., E. A. Laws, A. W. Morris, P. J. le B. Williams, AND S. Emerson. 2003. Metabolic balance of the open sea. Nature 426: 32, doi:10.1038/426032a

Knap, A. H., A. E. Michaels, A. Close, H. W. Ducklow, and A. G. Dickson. 1996. Protocols for the Joint Global Ocean Flux Study (JGOFS) core measurements. Bergen, Norway, UNESCO. JGOFS Report no. 19 (http://ijgofs.whoi.edu/ Publications/Report_Series/JGOFS_19.pdf).

Lepoint, G., S. Havelange, S. Gobert, and J.-M. Bouquegneau. 1999. Fauna vs flora contribution to the leaf epiphytes biomass in a Posidonia oceanica seagrass bed (Revellata Bay, Corsica). Hydrobiologia 394: 63-67, doi:10.1023/A:10035 57303904

Lionello, P., S. Cogo, M. B. Galati, and A. Sanna. 2008. The Mediterranean surface wave climate inferred from future scenario simulations. Glob. Planet. Change 63: 152-162, doi:10.1016/j.gloplacha.2008.03.004

Lorenzen, C. J., AND S. W. JefFrey. 1978. Determination of chlorophyll in seawater. UNESCO Tech. Pap. Mar. Sci. 35: $1-21$.

Luterbacher, J., M. A. Liniger, A. Menzel, N. Estrella, P. M. Della-Marta, C. Pfister, T. Rutishauser, and E. Xoplaki. 2007. Exceptional European warmth of autumn 2006 and winter 2007: Historical context, the underlying dynamics, and its phenological impacts. Geophys. Res. Lett. 34: L12704, doi:10.1029/2007GL029951

Marbà, N., And C. M. Duarte. 2010. Mediterranean warming triggers seagrass (Posidonia oceanica) shoot mortality. Glob. Change Biol. 16: 2366-2375, doi:10.1111/j.1365-2486. 2009.02130.x

-, M. A. Hemminga, M. A. Mateo, C. M. Duarte, Y. E. M. Mass, J. Terrados, and E. Gacia. 2002. Carbon and nitrogen translocation between seagrass ramets. Mar. Ecol. Prog. Ser. 226: $287-300$, doi:10.3354/meps 226287

Marty, J.-C., And J. Chiavérini. 2002. Seasonal and interannual variations in phytoplankton production at DYFAMED time-series station, northwestern Mediterranean Sea. Deep-Sea Res. II 49: 2017-2030, doi:10.1016/S09670645(02)00025-5

Mateo, M. A., J. Romero, M. Pérez, M. M. Littler, and D. S. LitTLER. 1997. Dynamics of millenary organic deposits resulting from the growth of the Mediterranean seagrass Posidonia oceanica. Estuar. Coast. Shelf Sci. 44: 103-110, doi:10.1006/ecss.1996.0116

Meinesz, A., G. Caye, F. Loquès, and H. Molenaar. 1991. Growth and development in culture of orthotropic rhizomes of Posidonia oceanica. Aquat. Bot. 39: 367-377, doi:10.1016/ 0304-3770(91)90010-3

Modigh, M., M. Lorenti, And L. Mazzella. 1998. Carbon assimilation in Posidonia oceanica: Biotic determinants. Bot. Mar. 41: 249-256, doi:10.1515/botm.1998.41.1-6.249

Odum, H. T. 1956. Primary production in flowing waters. Limnol. Oceanogr. 1: 102-117, doi:10.4319/lo.1956.1.2.0102

. 1963. Productivity measurements in Texas turtle grass and the effects of dredging an intracoastal channel. Publ. Inst. Mar. Sci. Univ. Tex. 6: 48-58. 
, AND R. F. Wilson. 1962. Further studies on reaeration and metabolism of Texas Bays, 1958-1960. Publ. Inst. Mar. Sci. Univ. Tex. 8: 23-55.

Pasqualini, V., C. Pergent-Martini, P. Clabaut, and G. Pergent. 1998. Mapping of Posidonia oceanica using aerial photographs and side scan sonar: Application off the Island of Corsica (France). Estuar. Coast. Shelf Sci. 47: 359-367, doi:10.1006/ecss.1998.0361

Pergent-Martini, C., V. Rico-Raimondino, and G. Pergent. 1994. Primary production of Posidonia oceanica in the Mediterranean Basin. Mar. Biol. 120: 9-15.

Peterson, B. J. 1980. Aquatic primary productivity and the ${ }^{14} \mathrm{C}-\mathrm{CO}_{2}$ method: A history of the productivity problem. Annu. Rev. Ecol. Syst. 11: 359-385, doi:10.1146/annurev.es. 11.110180.002043

Reyes, E., AND M. Merino. 1991. Diel dissolved oxygen dynamics and eutrophication in a shallow well-mixed tropical lagoon (Cancun, Mexico). Estuaries 14: 372-381, doi:10.2307/1352262

Santos, R., J. Silva, A. Alexandre, N. Navarro, C. Barrón, And C. M. Duarte. 2004. Ecosystem metabolism and carbon fluxes of a tidally dominated coastal lagoon. Estuaries 27: 977-985, doi:10.1007/BF02803424
Smith, S. V., and J. T. Hollibaugh. 1993. Coastal metabolism and the oceanic carbon balance. Rev. Geophys. 31: 75-89, doi:10.1029/92RG02584

Tengberg, A., AND OThers. 2006. Evaluation of a lifetime-based optode to measure oxygen in aquatic systems. Limnol. Oceanogr.: Methods 4: 7-17, doi:10.4319/lom.2006.4.7

Waycott, M., AND others. 2009. Accelerating loss of seagrasses across the globe threatens coastal ecosystems, Proc. Natl. Acad. Sci. USA 106: 12377-12381, doi:10.1073/pnas. 0905620106

Wollast, R. 1998. Evaluation and comparison of the global carbon cycle in the coastal zone and in the open ocean, p. 213-252. In K. H. Brink and A. R. Robinson [eds.], The global coastal ocean. Wiley.

Associate editor: Anthony W. D. Larkum

Received: 15 March 2011

Accepted: 19 October 2011 Amended: 25 October 2011 